This item was submitted to Loughborough's Research Repository by the author.

Items in Figshare are protected by copyright, with all rights reserved, unless otherwise indicated.

\title{
Controlled production of oil-in-water emulsions containing unrefined pumpkin seed oil using stirred cell membrane emulsification
}

PLEASE CITE THE PUBLISHED VERSION

http://dx.doi.org/10.1016/j.memsci.2008.05.026

PUBLISHER

(C) Elsevier

VERSION

AM (Accepted Manuscript)

LICENCE

CC BY-NC-ND 4.0

\section{REPOSITORY RECORD}

Dragosavac, Marijana M., Milan N. Sovilj, S.R. Kosvintsev, R.G. Holdich, and Goran T. Vladisavljevic. 2012. "Controlled Production of Oil-in-water Emulsions Containing Unrefined Pumpkin Seed Oil Using Stirred Cell Membrane Emulsification". figshare. https://hdl.handle.net/2134/10150. 
This item was submitted to Loughborough's Institutional Repository (https://dspace.lboro.ac.uk/) by the author and is made available under the following Creative Commons Licence conditions.

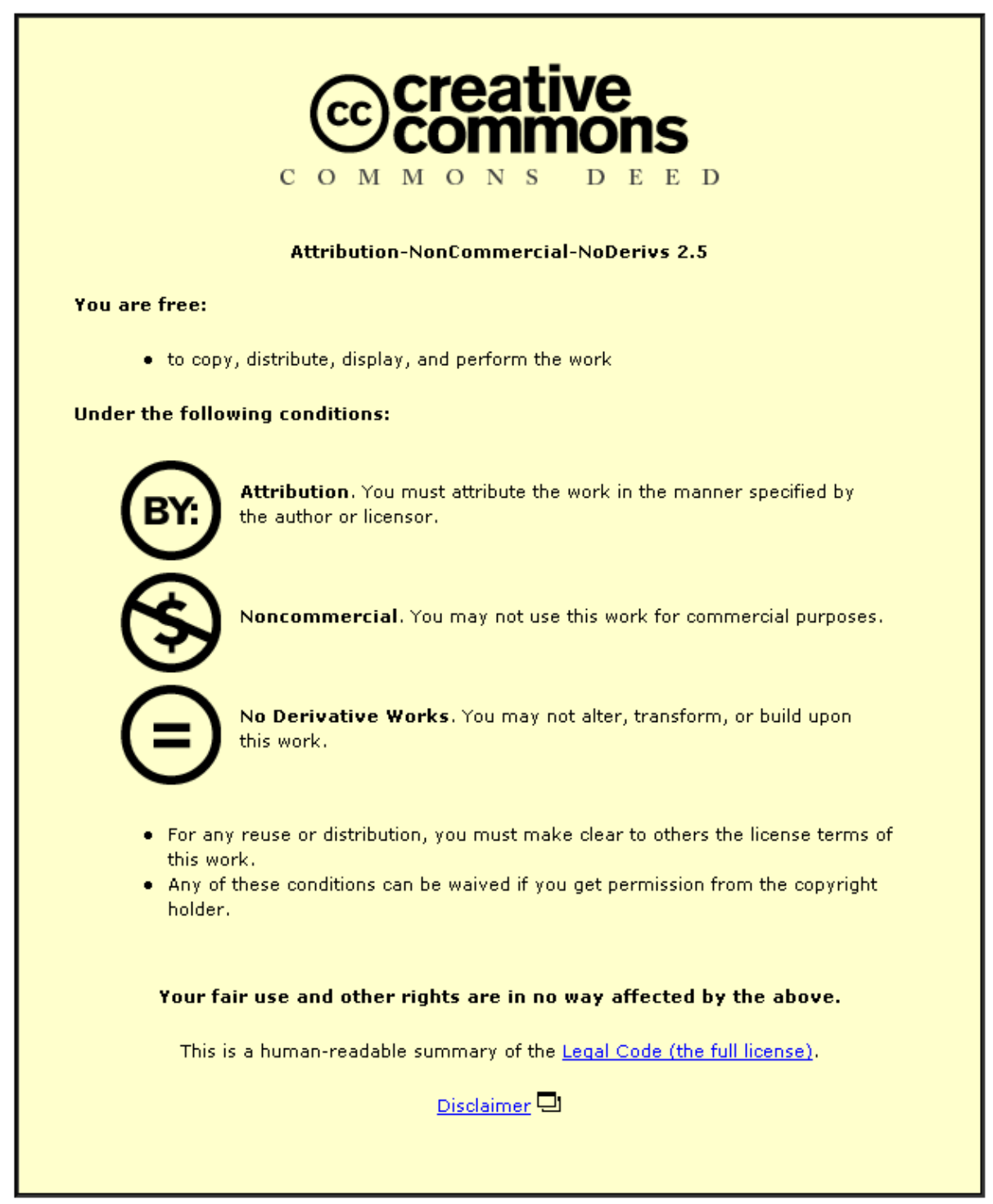

For the full text of this licence, please go to: http://creativecommons.org/licenses/by-nc-nd/2.5/ 


\title{
Controlled production of oil-in-water emulsions containing unrefined pumpkin seed oil using stirred cell membrane emulsification
}

\author{
Marijana M. Dragosavac, ${ }^{1}$ Milan N. Sovilj ${ }^{1}$, Serguei R. Kosvintsev, ${ }^{2}$ Richard G. Holdich, ${ }^{3}$ Goran \\ T. Vladisavljević ${ }^{3,4 *}$
}

\author{
${ }^{1}$ Faculty of Technology, Department of Chemical Engineering, University of Novi Sad, Bul. Cara \\ Lazara 1, YU-21000 Novi Sad, Serbia \\ ${ }^{2}$ Micropore Technologies Ltd., The Innovation Centre, Epinal Way, Loughborough, \\ Leicestershire, LE11 3EH, UK \\ ${ }^{3}$ Chemical Engineering Department, Loughborough University, Loughborough, Leicestershire \\ LE11 3TU, UK \\ ${ }^{4}$ Vinča Institute of Nuclear Sciences, PO Box 522, YU-11001 Belgrade, Serbia
}

\begin{abstract}
Membrane emulsification of unrefined pumpkin seed oil was performed using microengineered flat disc membranes on top of which a paddle blade stirrer was operated to induce surface shear. The membranes used were fabricated by galvanic deposition of nickel onto a photolithographic template and contained hexagonal arrays of uniform cylindrical pores with a diameter of 19 or 40 $\mu \mathrm{m}$ and a pore spacing of $140 \mu \mathrm{m}$. The uniformly sized pumpkin seed oil drops with span values less than 0.4 were obtained at oil fluxes up to $640 \mathrm{~L} \mathrm{~m}^{-2} \mathrm{~h}^{-1}$ using 2 wt.\% Tween 20

"Corresponding author: Phone: + 44 (0) 1509222 518; Fax: + 44 (0) 1509223923

e-mail address: G.Vladisavljevic@lboro.ac.uk
\end{abstract}


(polyoxyethylene sorbitan monolaurate) or 2-10 wt.\% Pluronic F-68 (polyoxyethylenepolyoxypropylen copolymer) as an aqueous surfactant solution. Pumpkin seed oil is rich in surface active ingredients that can be adsorbed on the membrane surface, such as free fatty acids, phospholipids, and chlorophyll. The adsorption of these components on the membrane surface gradually led to membrane wetting by the oil phase and the formation of uniform drops was achieved only for dispersed phase contents less than 10 vol.\%. At high oil fluxes, Pluronic F-68 molecules present at a concentration of 2 wt. \% could not adsorb fast enough, on the newly formed oil drops, to stabilise the expanding interface.

Keywords: Membrane emulsification; stirred cell; pumpkin seed oil; food emulsions; microsieve membrane.

\section{Introduction}

Membrane emulsification is a relatively new method of producing micron-sized emulsion droplets of a predefined size, based on the extrusion of the dispersed phase into the continuous phase liquid through a microporous membrane [1-2]. In addition to the direct process, in which a pure dispersed phase is forced through the membrane, other modes of operation have also been developed, such as premix membrane emulsification, or membrane homogenisation, in which a coarse emulsion is homogenised by passing through the membrane in a single pass or several consecutive passes [3-5]. Another interesting novel approach in membrane emulsification is the formation of drops through fragmentation of the dispersed phase in the lumen of hollow fibre membranes due to permeation of pure continuous phase through the membrane [6]. The main application areas of membrane emulsification are production of double emulsions [4-5, 7-8], 
creation of drops for biphasic enzymatic reactions [9], and production of solid microparticles [10], such as solid lipid microcapsules [11], polymeric microspheres [12], silica particles [13], and gel microbeads [14].

In order to detach droplets from the membrane surface and allow better control over the droplet size distribution, the shear stress is usually controlled at the surface of the membrane. The surface shear can be created by recirculating the continuous phase in cross flow (Figure 1(a)) [12], by vibrating [15-16] or rotating the membrane (Figures 1 (b) and (d)) [17-19], by vibrating an element (e.g. a wire or plate) in the continuous phase at a short distance from the membrane (Figure 1(c)) [20-21] or by stirring the continuous phase using a stirring bar (Figure 1(f)) [22-23] or a paddle stirrer (Figure 1(e)) [24-26]. Table 1 lists potential advantages and disadvantages of the various techniques used for generation of surface shear in membrane emulsification. Cross flow is the most conventional way to control shear force in direct membrane emulsification [2]. If the surfactant has sufficient time to stabilise the interface so that the drops do not coalescence, a regular droplet detachment from the membrane surface and formation of uniform drops can be achieved even without any surface shear, providing that the drops are strongly deformed from their preferred spherical shape before detachment. It may happen if there is a large number of drops at the membrane surface and the drop diameter is bigger than the distance between the pores, so that the drops push each other at the membrane surface [27]. The drops can also be deformed from their spherical shape if they are generated at the pores or channels with a distinct non-spherical shape such as rectangular channels with a high aspect ratio [28] and asymmetric microchannels [29] or if the droplets are squeezed between a microstructured substrate and a cover glass before detachment [30]. However, it is widely accepted that the shear stress at the membrane surface does have to be applied to obtain uniform drops at relatively high drop productivity. As a rule, the higher the injection rate of the dispersed phase, the greater the surface 
shear stress that has to be applied to enhance the monodisperse nature of the particle size distribution [31].

In this work membrane emulsification was performed using microengineered flat disc membranes on top of which a paddle blade stirrer was operated to induce surface shear (Figure 1 (e)). A stirred cell is an unusual device for membrane emulsification, because it is commonly believed that a uniform shear field at the membrane surface is required for the generation of uniformly sized drops. However, in the previous studies [24-25], it was found that a stirred cell with a varying radial shear field at the surface of the flat disc membrane could produce uniformly sized drops of paraffin wax and refined sunflower oil. In this work the same stirred cell was used to produce emulsions of unrefined pumpkin seed oil. This system presents a significant challenge because unrefined pumpkin seed oil contains a broad range of components that not only have beneficial health effects, but may also be adsorbed on the membrane surface and hinder the emulsification process. Unrefined pumpkin seed oil is particularly rich in omega-3 fatty acids [32], ranking second only to flax seed and should be emulsified under low shear conditions to avoid heating and lipid oxidation. Therefore, membrane emulsification seems to be a very convenient technique for production of emulsions of unrefined pumpkin seed oil of high biological value and desired organoleptic properties.

\section{Experimental}

\subsection{Materials}


The oil phase in $\mathrm{O} / \mathrm{W}$ emulsions was unrefined pumpkin seed oil with a density of $913 \mathrm{~kg}$ $\mathrm{m}^{-3}$ and viscosity of $55 \mathrm{mPa}$ s at $298 \mathrm{~K}$, kindly donated by GEA Tovarna Olja (Slovenia). The continuous phase was 2 wt.\% Tween ${ }^{\circledR} 20$ (Polyoxyethylene sorbitan monolaurate from Fluka, UK) or 1-10 wt.\% Pluronic ${ }^{\circledR}$ F-68 (difunctional polyoxyethylene-polyoxypropylen copolymer from Sigma-Aldrich, UK), as can be seen in Table 2. The density of oil and continuous phase was measured using an Anton Paar digital density meter (model DMA 46, Graz, Austria). The oil viscosity was measured using HAAKE RheoStress ${ }^{\circledR}$ model RS600 rheometer with sensor C60/1 ${ }^{\circ}$ Ti and a gap of $51 \mu \mathrm{m}$ (Thermo Electron, Karlsruhe, Germany). The continuous phase viscosities were measured with a Cannon-Ubbelohde model 9721-K50 viscometer (CANNON ${ }^{\circledR}$ Instrument Company, USA). The equilibrium interfacial tensions at oil/water interface were measured by the Du Nouy ring method using a White Electric Instrument tensiometer (model DB2KS). The physical properties of the surfactant solutions and the equilibrium interfacial tensions for the two different oils used are listed in Table 3. Refined sunflower oil (food grade from a local supermarket) was used as a standard for comparison.

\subsection{Membranes and membrane module}

The emulsions were obtained using a stirred cell with a flat disc membrane under the paddle blade stirrer, as shown in Figure 2. Both stirred cell and membranes were supplied by Micropore Technologies Ltd. (Loughborough, UK). The agitator was driven by a 24V DC motor (INSTEK Model PR 3060) and paddle rotation speed in the range from 232 to $1326 \mathrm{rpm}$ was controlled by the applied voltage. The membranes used were nickel membranes containing uniform cylindrical pores with a diameter of $d_{p}=19$ or $40 \mu \mathrm{m}$ and a pore spacing of $\mathrm{L}=140 \mu \mathrm{m}$. The membranes 
were fabricated by galvanic deposition of nickel onto a template formed by photolithographic technique. A perfectly ordered hexagonal array of pores with a pore at the centre of each hexagonal cell can be seen on the micrographs in Figures 3 (c) and 3 (d) and it is schematically presented in Figure 3 (e). The porosity of a membrane with the hexagonal pore array is given by:

$$
\varepsilon=\frac{\pi}{2 \sqrt{3}}\left(\frac{\mathrm{d}_{\mathrm{p}}}{\mathrm{L}}\right)^{2}
$$

For the membranes used in this work, the porosity calculated from Equation (1) is 1.7 and $7.4 \%$ for $\mathrm{d}_{\mathrm{p}}=19$ and $40 \mu \mathrm{m}$, respectively.

The previous studies of stirred cell emulsification [25] have shown that shear stress was not uniformly distributed over the membrane surface. The shear stress is greatest at a radial distance $\mathrm{r}_{\text {trans, }}$, corresponding to the transition between the forced and free vortex around the stirrer. For the stirrer speeds and surfactant solutions used in this work, the transitional radius $r_{\text {trans }}$ varies from 7 to $12 \mathrm{~mm}$, as can be seen in Figures 14 and 15 and discussed in the Appendix. The region on the membrane surface in the vicinity of $r_{\text {trans }}$ is the most effective in terms of drop productivity and has the greatest potential to generate uniformly size drops. In order to investigate the influence of shear profile on the drop formation, two different membranes have been investigated, the standard membrane having the pores open over the whole membrane surface (Figure 3 (b)) and the ring membrane in which the injection zone was restricted to a narrow annular region around the transitional radius, as shown in Figure 3 (a). The position of injection zone from $\mathrm{r}_{1}=7 \mathrm{~mm}$ to $r_{2}=13$ mm ensures that $r_{\text {trans }}$ lies between $r_{1}$ and $r_{2}$ in all experimental runs. The effective crosssectional area of the whole and ring membrane was 8.5 and $3.8 \mathrm{~cm}^{2}$, respectively, while the number of pores in the injection zone was 50,400 and 22,200, respectively. 


\subsection{Experimental procedure}

Prior to emulsification, the membrane was pre-soaked in a wetting agent for at least 30 min to increase the hydrophilicity of the surface. Pumpkin seed oil was injected through the membrane using a peristaltic pump (Watson-Marlow-Bredel Pump 101U/R, Cornwall, UK) at the constant flow rate of 3 to $50 \mathrm{~mL} \mathrm{~min}^{-1}$, corresponding to the dispersed phase flux of 187 to 3190 $\mathrm{L} \mathrm{m}^{-2} \mathrm{~h}^{-1}$. The initial volume of surfactant solution in the cell was $125 \mathrm{~cm}^{3}$ and the experiments were typically run until the dispersed phase concentration reached 5 vol. \%. Once the desired amount of oil had passed through the membrane, both the pump and the agitator were switched off and the droplets were collected and analyzed. The membrane was cleaned with $8 \mathrm{M} \mathrm{NaOH}$ in an ultrasonic bath for 5 minutes followed by treatment in $10 \mathrm{vol} \% \mathrm{HCl}$ solution for 5 minutes. To evaluate the drop-size distribution and droplet diameter, a laser diffraction particle size analyzer (Malvern Mastersizer, Model S) was used. For each emulsion, three separate samples and measurements were performed and the mean average of these is reported. The mean particle size was expressed as the volume median diameter $\mathrm{d}(\mathrm{v}, 0.5)$, which is the diameter corresponding to 50 vol. $\%$ on the cumulative distribution curve. The relative span of a drop size distribution was used to express the degree of drop size uniformity: span $=[d(v, 0.9)-d(v, 0.1)] / d(v, 0.5)$. The micrographs of membrane surface were taken using a Leitz Ergolux optical microscope. 


\section{Results and discussion}

\subsection{Influence of membrane type and dispersed phase flux}

Figure 4 shows the effect of dispersed phase flux on the droplet size at a constant rotational speed of $596 \mathrm{rpm}$ for the whole and ring membrane with a same pore size of $19 \mu \mathrm{m}$. It is possible to notice that the droplet size and span values were virtually the same for both membranes under the same experimental conditions. It can be explained by the fact that the average shear stress at a stirrer speed of $596 \mathrm{rpm}$ increases just by $13 \%$ when the injection zone is restricted to a narrow ring region surrounding the transitional radius, as can be seen in Figure 5. This figure clearly shows that shear stresses at the membrane surface are low values even at very high stirrer speeds and that constant temperature operation can be assumed. Hence, thermo-sensitive ingredients of pumpkin seed oil, such as unsaturated fatty acids are fully preserved during emulsification. A comparison between the shear stress distribution at the membrane surface for the whole and ring membrane is presented in Figure 6. The span factor was calculated using the equation: span = $[\tau(\mathrm{A}, 0.9)-\tau(\mathrm{A}, 0.1)] / \tau(\mathrm{A}, 0.5)$, where $\tau(\mathrm{A}, 0 . \mathrm{X})$ is the $\tau$ value corresponding to the value of $\mathrm{X} 0 \%$ on the shear stress distribution curve shown in Figure 6. This figure suggests that over $82 \%$ of the membrane area, the local shear stress $\tau$ varies within the narrow interval of $2.86-4.63 \mathrm{~Pa}$ for both the whole and ring membrane. Over only $18 \%$ of the total area, the shear stress for the whole membrane is lower than $2.86 \mathrm{~Pa}$ and this low shear zone is located near the center of the membrane, as suggested by Eq. (A1) in Appendix. However, since the continuous phase pressure above the low shear zone is the greatest in magnitude, the transmembrane flux in this zone is the lowest. Thus, the number of drops produced in the low shear zone is a small fraction of the 
overall drop population and the drop size distribution is virtually the same for both membranes. One of the obvious disadvantages of the ring membrane is a lower drop production rate at the same flux, due to 2.2 times lower area of the injection zone. In the remaining text, no further discussion on the type of membrane used (ring or whole) will be given, as no significant differences in their performances were noticed, for this investigated system.

The drop size initially increases linearly with increasing the dispersed phase flux up to 1300 $\mathrm{L} \mathrm{m}^{-2} \mathrm{~h}^{-1}$, and then increases more slowly with further increase in flux. The droplet size increase with dispersed phase flux can be explained by assuming a constant drop detachment time. Hence, the increase of dispersed phase flux results in an increase in the amount of oil flowed into a drop during the detachment process, and the formation of larger droplets [33]. In addition, when the dispersed phase flux is increased, the drop grows faster and the interface cannot be stabilized fast enough by adsorbed emulsifier molecules, as pointed out by some authors [34, 35]. A higher interfacial tension force keeps the drop attached to the pore for a longer time, leading to a greater drop size at snap-off.

As can be seen in Figure 4, the linear drop diameter-flux relationship is maintained up to $\mathrm{d}(\mathrm{v}, 0.5)$ value of $175 \mu \mathrm{m}$, which corresponds to $\mathrm{d}(\mathrm{n}, 0.5)$ value of around $140 \mu \mathrm{m}$ at which neighboring drops start to interact with each other on the membrane surface when formed at the same time. A slow increase in drop size at high flux values is a consequence of the existence of push-off force which assists in the detachment of drops from the membrane surface [27]. The push-off force does not exist within the linear section of the plot because the drops are too small to be deformed to an appreciable extent by the neighbouring drops on the membrane surface. The occurrence of steric hindrance at high fluxes is caused not only by formation of larger drops, but also due to increase in the fraction of active pores which leads to a decrease in average distance 
between neighbouring drops. Figure 4 shows that uniformly sized drops with the span values less than 0.4 were only obtained at the oil fluxes up to $640 \mathrm{~L} \mathrm{~m}^{-2} \mathrm{~h}^{-1}$. The limiting flux for the creation of uniform drops is, however, much higher than that observed when using the matrix type of membranes, such as ceramic and SPG types $[31,36]$.

\subsection{Influence of oil type and pore size}

Figures 7 and 8 compares the drop size and span of size distributions for emulsions of pumpkin seed oil and sunflower oil produced under the same conditions using membranes with pore sizes of 19 and $40 \mu \mathrm{m}$, respectively. Neglecting a lag time in the drop formation process and assuming that all pores are active, the material balance equation for dispersed phase can be written in the form: $J_{d} A_{p} / \varepsilon=V_{d} / t$, where $A_{p}$ is the cross-sectional area of a single pore, $V_{d}$ is the drop volume and $t_{d}$ is the drop formation time. Using this equation and Eq. (1), one obtains:

$$
\mathrm{t}_{\mathrm{d}}=\frac{\pi \mathrm{d}_{(\mathrm{v}, 0.5)}^{3}}{3 \sqrt{3} \mathrm{~L}^{2} \mathrm{~J}_{\mathrm{d}}}
$$

The calculated drop formation times, $\mathrm{t}_{\mathrm{d}}$, for the conditions as in Figure 7 are in the range of 0.590.88 and $0.30-0.54 \mathrm{~s}$ for the sunflower oil and pumpkin seed oil, respectively. Using dynamic interfacial tension data for 2 wt.\% Tween 20 given by Schröder et al. [34] and the equilibrium interfacial tensions from Table 3, we have found that the dynamic interfacial tension at the moment the detachment started was in the range of $6.5-8.7$ and 4.4-5.7 $\mathrm{mN} \mathrm{m}^{-1}$ for the sunflower oil and pumpkin seed oil, respectively. Therefore, the larger sunflower oil drops in Figure 7 can be attributed to the greater dynamic interfacial tensions at the sunflower oil interface as compared to the values at the pumpkin seed oil interface. The difference in drop diameter between sunflower oil and pumpkin seed oil predicted using Model III from the appendix is significantly 
greater than the actual difference observed at the flux of $187 \mathrm{~L} \mathrm{~m}^{-2} \mathrm{~h}^{-1}$. It can be explained by the fact that the model equations are valid in the limiting case of zero flux and under such condition the system is in adsorption equilibrium and the equilibrium interfacial tensions are relevant. The ratio of the equilibrium interfacial tensions for the two oils of 3.3 calculated from Table 3 is much greater than the ratio of their dynamic interfacial tensions at the moment of detachment.

Membrane pore size is another important parameter that affects the drop size. At the dispersed phase flux of $187 \mathrm{~L} \mathrm{~m}^{-2} \mathrm{~h}^{-1}$, the size of pumpkin oil drops increases by a factor of 1.8 when the pore size is changed from 19 to $40 \mu \mathrm{m}$, as can be seen from Figures 7 and 8 . The influence of pore size on the mean drop size is less pronounced at the higher dispersed phase fluxes, because under these conditions the drop size is more affected by the interaction between the droplets.

The graphs in Figures 7 and 8 describe the experiments in which the final dispersed phase content in the emulsions was kept constant at 5 vol.\%. Figure 9 demonstrates that the pumpkin seed oil drops were significantly larger than the sunflower oil drops when the dispersed phase content in the emulsions was is in the range from 10 to 30 vol.\%. The reason for this behaviour is the fact that unrefined pumpkin seed oil is rich in many compounds that can be adsorbed on the membrane surface, such as free fatty acids, minerals, phospholipids, chlorophyll, and aromatic components. The adsorption of these components on the membrane surface gradually leads to membrane wetting by the oil phase. As a result of the membrane wetting, the span values for pumpkin seed oil emulsions with a dispersed phase content from 10 to 30 vol. \% were in the range between 0.7 and 1.0, as shown in Figure 9. On the other hand, due to the fact that refined vegetable oils contain predominantly non-adsorbing triglycerides, no significant variation in the span values was observed for sunflower oil emulsions over the investigated range of dispersed 
phase content between 5 and 60 vol. $\%$. When the oil phase does not wet the membrane, the expansion of the contact area drop/membrane is energetically unfavourable, as noted by Christov

et al. [37] and the contact line tends to be constant and restricted to the pore perimeter. As a result, relatively small and uniform drops are formed, as in the case of the sunflower oil drops. When the the contact angle is increased, the drop does not detach exactly at the pore tip, but the contact line drop/membrane expands over the larger surface. In that case the drops are formed from non-uniform hydrophobised domains on the membrane surface, rather than from the individual pores [37]. As a result, the formed drops are larger and more polydisperse reflecting the size distribution of the hydrophobised domains. In the case of a highly-porous membrane with interconnected pores such as SPG membrane, the hydrophobised domains can be extended over the surface of two or more pores and thus, a growing drop can be fed through several pores [37]. In the case of our microsieve membrane, due to a large interpore distance we believe that the drops formed at hydrophobised microdomains are fed through a single pore.

\subsection{Influence of emulsifier}

Figure 10 illustrates the effect of two different non-ionic emulsifiers (low molecular weight Tween 20 and medium molecular weight Pluronic F-68) on the mean size of pumpkin seed oil drops and the span of size distribution. A surfactant concentration of 2 wt. \% used was above Tween 20's critical micellar concentration (CMC) of 0.98 wt.\% [38], but lower than a CMC value of 9.2 wt.\% for Pluronic F-68 [39]. As can be seen, the smaller drops are formed in the presence of Tween 20, which is a consequence of the lower equilibrium interfacial tension $(\gamma=$ 1.5 and $6 \mathrm{mN} \mathrm{m}^{-1}$ for 2 wt.\% Tween 20 and Pluronic F-68, respectively, see Table 3) and a faster 
adsorption of Tween 20 molecules at the interface. For the dispersed phase flux less then $1300 \mathrm{~L}$ $\mathrm{m}^{-2} \mathrm{~h}^{-1}$, the span is not significantly affected by the type of emulsifier added. However, beyond the flux value of $1300 \mathrm{~L} \mathrm{~m}^{-2} \mathrm{~h}^{-1}$, the drops are much more uniform is size, when formed in the presence of Tween 20. This can be explained by assuming that Pluronic F-68 molecules cannot adsorb fast enough on the oil drops to stabilize the interface at a high volume expansion rate. The molecular weight of Pluronic F-68 and Tween 20 is 8350 and $1227 \mathrm{~g} \mathrm{~mol}^{-1}$, respectively. Hence, Pluronic F-68 molecules diffuse more slowly to the interface. The loading of the interface with surfactant (in $\mathrm{mol} \mathrm{m}^{-2}$ ) is directly proportional to $(\mathrm{Dt})^{0.5}$, where $\mathrm{t}$ is the interfacial age and $\mathrm{D}$ is the surfactant diffusion coefficient [40]. On the other hand, the dynamic interfacial tension linearly increases with (Dt $)^{-0.5}[35,37]$. Figure 11 clearly shows that the size of pumpkin oil drops can effectively be reduced by increasing the concentration of Pluronic F-68 from 2 to $10 \mathrm{wt} . \%$, which is slightly above a CMC value of $9.2 \mathrm{wt}$. \%. It is a consequence of two factors: (i) a decrease in equilibrium interfacial tension from 6.0 to $4.5 \mathrm{mN} \mathrm{m}^{-1}$ which reduces the dynamic interfacial tension and the capillary force at the moment of breakup; (ii) increase in viscosity of continuous phase from 1.28 to $4.48 \mathrm{mPa} \mathrm{s}$ (Table 3), which increases the drag force on droplets at the same stirrer speed. Due to both effects the drops are sooner detached from the membrane surface and the final drop size is reduced.

\subsection{Influence of surface shear stress}

Figure 12 demonstrates the dependence of the droplet size distribution with the rotational speed for emulsions of pumpkin seed oil at the oil flux of $318 \mathrm{~L} \mathrm{~m}^{-2} \mathrm{~h}^{-1}$. As found earlier for the sunflower oil-in-water emulsions [24-25], the droplet size decreases with increasing the stirrer 
speed due to an increase in the drag force acting on droplets. The droplet size is a strong function of stirrer speed up to $600 \mathrm{rpm}$ corresponding to average shear stress at the membrane surface of 4 $\mathrm{Pa}$, but less so at higher stirrer speeds. At the stirrer speeds above $1100 \mathrm{rpm}$, the median drop size is virtually independent on the stirrer speed and more than 3 times smaller than that at $232 \mathrm{rpm}$. Figure 13 provides a comparison of experimental drop sizes and model predictions at different speeds of rotation. The shear-capillary models used here (see Appendix) does not recognise the dispersed phase flux rate as having a contribution to the formed drop size. Thus, it is possible to hypothesise that the models represent the smallest drop size that can be produced for a given set of operating conditions. In Figure 13, it can be seen that the experimental drop sizes at a dispersed phase flux of $232 \mathrm{~L} \mathrm{~m}^{-2} \mathrm{~h}^{-1}$ are larger than the model predictions. At very low dispersed phase flux the models should be in very good agreement with the measured values for median drop size. Using a given peristaltic pump, we could not obtain a flux value less than $232 \mathrm{~L} \mathrm{~m}^{-2} \mathrm{~h}^{-}$ ${ }^{1}$. So, in order to estimate the validity of model equations, the experimental median drop sizes are extrapolated to zero flux and plotted in Figure 13 along with the theoretical lines. As can be seen, when the dispersed phase flux approaches zero, Model III gives a good approximation to the median drop size and only slightly underestimates the drop size. It is clear that all three models give similar predictions for high rotational speeds and the predicted drop sizes are in excellent agreement with the experimental values extrapolated to zero flux. At low shear stresses, Models I and II are not successful, because the necking phenomenon [33,34] cannot be neglected and Model III does take into account necking between the forming drop and the pore. 


\section{Conclusions}

Unrefined pumpkin seed oil-in-water emulsions with a narrow particle size distribution and volume median diameters from 70 to $270 \mu \mathrm{m}$ were produced by injecting the oil phase through microsieves, manufactured from nickel by galvanic coating, with a hexagonal array of pores of 19 or $40 \mu \mathrm{m}$ diameter. The shear stress at the membrane surface was provided by agitating a continuous phase liquid ( 2 wt.\% Tween 20 or $2-10$ wt. \% Pluronic F-68) using a simple paddle blade stirrer. The particle size distribution for a given pore size can precisely be controlled by adjusting the dispersed phase flux and stirrer speed and by an appropriate choice of emulsifier and emulsification time. The drop size initially increases linearly with increasing the oil flux and then increases more slowly with a further flux increase. The uniformly sized drops with the span values less than 0.4 were only obtained at the oil fluxes up to $640 \mathrm{~L} \mathrm{~m}^{-2} \mathrm{~h}^{-1}$. Over the range of dispersed phase content from 0 to 5 vol.\%, the drops of sunflower oil were larger than the pumpkin seed oil drops produced under the same operating conditions, which was attributed to the higher dynamic interfacial tension at the sunflower oil/aqueous phase interface. For dispersed phase contents in the range of 10-30 vol.\%, the drops of pumpkin seed oil were significantly larger and more polydisperse than sunflower oil drops, which was due to the adsorption of surface active ingredients of unrefined pumpkin seed oil on the membrane surface, such as colouring and aromatic components, free fatty acids, and phospholipids. For the high dispersed phase fluxes and the surfactant content in the continuous phase of $2 \mathrm{wt} . \%$, the pumpkin seed oil drops were much smaller and less polydisperse, when formed in the presence of Tween 20, because under these conditions Pluronic F-68 molecules cannot adsorb fast enough on the oil drops to stabilise the interface. However, the size of pumpkin seed oil drops can be reduced by 
increasing the concentration of Pluronic F-68 from 2 to $10 \mathrm{wt} . \%$. The shear-capillary models used to predict the resultant drop sizes provide good predictions under the conditions of high rotational speeds and low dispersed phase fluxes. At low rotational speeds, the drops are relatively large and the shear-capillary model must take into account necking between the forming drop and the pore. In spite of a non-uniform shear profile on the membrane surface, the drop size uniformity was not improved when the injection zone for oil phase was restricted to a narrow ring region where the shear stress magnitude was greatest.

Due to low shear forces in the continuous phase and constant temperature operation, stirred cell membrane emulsification has a great potential to produce emulsions of unrefined pumpkin seed oil of high biological value and desired organoleptic properties with a controlled drop size distribution. Our future work will be focused on the application of Micropore Dispersion Cell to the production of uniform multiple emulsions of pumpkin seed oil.

\section{Appendix}

The shear stress at the membrane surface varies, $\tau$, with the radial distance from the centre, $\mathrm{r}$, according to the equations [41]:

$$
\begin{array}{ll}
\text { For } \mathrm{r}<\mathrm{r}_{\text {trans }} & \tau=0.825 \eta \omega \mathrm{r} \frac{1}{\delta} \\
\text { For } \mathrm{r}>\mathrm{r}_{\text {trans }} & \tau=0.825 \eta \omega \mathrm{r}_{\text {trans }}\left(\frac{\mathrm{r}_{\text {trans }}}{\mathrm{r}}\right)^{0.6} \frac{1}{\delta}
\end{array}
$$

where $r_{\text {trans }}$ is the transitional radius, i.e. the radial distance at which the shear stress is greatest:

$$
\mathrm{r}_{\text {trans }}=1.23 \frac{\mathrm{D}}{2}\left(0.57+0.35 \frac{\mathrm{D}}{\mathrm{T}}\right)\left(\frac{\mathrm{b}}{\mathrm{T}}\right)^{0.036} \mathrm{n}_{\mathrm{b}}^{0.116} \frac{\mathrm{Re}}{1000+1.43 \mathrm{Re}}
$$


Here, $\mathrm{D}$ is the stirrer diameter, $\mathrm{T}$ is the tank (cell) diameter, $\mathrm{b}$ is the blade height, and $\mathrm{n}_{\mathrm{b}}$ is the number of impeller blades. The Reynolds number is defined by $\operatorname{Re}=\omega \rho \mathrm{D}^{2} /(2 \pi \eta)$, where $\rho$ and $\eta$ is the continuous phase density and viscosity, respectively, and $\omega$ is the angular velocity.

The boundary layer thickness, $\delta$, is defined by the Landau-Lifshitz equation [42]

$$
\delta=\sqrt{\frac{\eta}{\rho \omega}}
$$

The local values of shear stress are plotted in Figure 14, and the position of the transitional radius is plotted as a function of stirrer rotation speed in Figure 15. The average shear stress at the membrane surface for the standard (whole) membrane can be obtained from Equations (A1) and (A2):

$$
\begin{aligned}
\tau_{\mathrm{av}}= & \frac{\int_{0}^{\mathrm{r}_{\text {tans }}} 0.825 \eta \omega \mathrm{r} \frac{1}{\delta}(2 \pi \mathrm{r}) \mathrm{dr}+\int_{\mathrm{r}_{\text {rans }}}^{\mathrm{D}_{\mathrm{m}} / 2} 0.825 \eta \omega \mathrm{r}_{\text {trans }}\left(\frac{\mathrm{r}_{\text {trans }}}{\mathrm{r}}\right)^{0.6} \frac{1}{\delta}(2 \pi \mathrm{r}) \mathrm{dr}}{\pi \mathrm{D}_{\mathrm{m}}^{2} / 4}= \\
= & \frac{6.6}{\mathrm{D}_{\mathrm{m}}^{2}} \eta \omega \frac{1}{\delta}\left\{\frac{\mathrm{r}_{\text {trans }}^{3}}{3}+\frac{\mathrm{r}_{\text {trans }}^{1.6}}{1.4}\left[\left(\frac{\mathrm{D}_{\mathrm{m}}}{2}\right)^{1.4}-\mathrm{r}_{\text {trans }}^{1.4}\right]\right\}
\end{aligned}
$$

where $D_{m}$ is the effective membrane diameter (Fig. 2). The average shear stress for the ring membrane providing that $r_{1}<r_{\text {trans }}<r_{2}$ is given by:

$$
\begin{aligned}
\tau_{\mathrm{av}}= & \frac{\int_{\mathrm{r}_{1}}^{\mathrm{r}_{\text {rans }}} 0.825 \eta \omega \mathrm{r} \frac{1}{\delta}(2 \pi \mathrm{r}) \mathrm{dr}+\int_{\mathrm{r}_{\text {rans }}}^{\mathrm{r}_{2}} 0.825 \eta \omega \mathrm{r}_{\text {trans }}\left(\frac{\mathrm{r}_{\text {trans }}}{\mathrm{r}}\right)^{0.6} \frac{1}{\delta}(2 \pi \mathrm{r}) \mathrm{dr}}{\pi\left(\mathrm{r}_{2}^{2}-\mathrm{r}_{1}^{2}\right)}= \\
= & \frac{1.65}{\mathrm{r}_{2}^{2}-\mathrm{r}_{1}^{2}} \eta \omega \frac{1}{\delta}\left[\frac{\mathrm{r}_{\text {trans }}^{3}-\mathrm{r}_{1}^{3}}{3}+\frac{\mathrm{r}_{\text {trans }}^{1.6}}{1.4}\left(\mathrm{r}_{2}^{1.4}-\mathrm{r}_{\text {trans }}^{1.4}\right)\right]
\end{aligned}
$$

The maximum shear stress $\tau_{\max }$ is calculated using Equations (A1) or (A2) with $r=r_{\text {trans: }}$ :

$$
\tau_{\max }=0.825 \eta \omega \mathrm{r}_{\text {trans }} \frac{1}{\delta}
$$


The droplet diameter $\mathrm{x}$ can be predicted from a simple force balance at the pore exit: $\mathrm{F}_{\mathrm{d}}=$ $\mathrm{F}_{\mathrm{ca}}$, where $\mathrm{F}_{\mathrm{ca}}$ and $\mathrm{F}_{\mathrm{d}}$ are the capillary and drag force, respectively [24]:

$$
\begin{aligned}
& \mathrm{F}_{\mathrm{ca}}=\pi \mathrm{d}_{\mathrm{p}} \gamma \\
& \mathrm{F}_{\mathrm{d}}=9 \pi \tau \mathrm{x} \sqrt{(\mathrm{x} / 2)^{2}-\mathrm{r}_{\mathrm{p}}^{2}}
\end{aligned}
$$

where $r_{p}$ is the pore radius and $\gamma$ is the interfacial tension. Solving Equations (A8) and (A9) for $x$ gives [24-25]:

$$
x=\frac{\sqrt{18 \tau^{2} r_{p}^{2}+2 \sqrt{81 \tau^{4} r_{p}^{4}+4 r_{p}^{2} \tau^{2} \gamma^{2}}}}{3 \tau}
$$

Three different models for predicting dispersed phase drop size have been used here. Model I is based on Equation (A10), in which $\tau=\tau_{\mathrm{av}}$. Model II uses the same equation (A10) and assumes that $\tau=\tau_{\max }$. It is based on the assumption that the pressure on the surface of the membrane is lowest at $\tau=\tau_{\max }$, hence the majority of drops are formed near this point and $\tau_{\max }$ is a good approximation for the average shear stress.

Model III uses the modified expression for the capillary force to consider the neck, which exists between the forming drop and the membrane pore, by introducing another force called Static force, $\mathrm{F}_{\text {stat }}[33,34]$ :

$$
\mathrm{F}_{\mathrm{ca}}-\mathrm{F}_{\text {stat }}=\pi \mathrm{d}_{\mathrm{p}} \gamma-\frac{4 \gamma}{\mathrm{x}} \frac{\pi}{4} \mathrm{~d}_{\mathrm{p}}^{2}=\pi \mathrm{d}_{\mathrm{p}} \gamma\left(1-\mathrm{d}_{\mathrm{p}} / \mathrm{x}\right)
$$

If the droplet diameter is smaller than twice the pore diameter, $F_{\text {stat }}$ is ignored and Eq. (A8) should be used, since Equation (A11) is no longer valid. The expression for the drag force is based on Stokes's drag expression, with a correction factor $\mathrm{k}_{\mathrm{wl}}=3.4926$ to consider the effect of the nearby walls in the motion of a droplet, as reported in [43]:

$$
\mathrm{F}_{\mathrm{d}}=3 \pi \mathrm{k}_{\mathrm{wl}} \eta \mathrm{vx}
$$




\section{9 out of 45}

where $\mathrm{v}$ is the relative velocity between the drop and the continuous phase:

$$
\mathrm{v}=\omega \mathrm{r}_{\text {trans }}\left(1-\exp \left(-\frac{\mathrm{x}}{2 \delta}\right)\right)
$$

Predicted droplet diameter $\mathrm{x}$ is calculated from a force balance equation $\mathrm{F}_{\mathrm{d}}=\mathrm{F}_{\mathrm{ca}}-\mathrm{F}_{\text {stat }} \mathrm{using}$ Equations (A11), (A12) and (A13). In this work, this force balance equation was solved numerically using MathCad 2001 Professional, MathSoft, Inc. 


\section{List of Symbols}

\begin{tabular}{|c|c|}
\hline$A_{p}$ & Cross-sectional area of pore, $\mathrm{m}^{2}$ \\
\hline $\mathrm{b}$ & blade height, $\mathrm{m}$ \\
\hline $\mathrm{D}$ & stirrer diameter, $\mathrm{m}$ \\
\hline $\mathrm{D}_{\mathrm{m}}$ & effective membrane diameter, $\mathrm{m}^{2}$ \\
\hline$d_{\mathrm{p}}$ & pore diameter, $\mathrm{m}$ \\
\hline $\mathrm{d}(\mathrm{n}, 0.5)$ & number median drop diameter, $\mathrm{m}$ \\
\hline $\mathrm{d}(\mathrm{v}, 0.5)$ & volume median drop diameter, $\mathrm{m}$ \\
\hline $\mathrm{F}_{\text {stat }}$ & static force, $\mathrm{N}$ \\
\hline $\mathrm{F}_{\mathrm{ca}}$ & capillary or interfacial tension force, $\mathrm{N}$ \\
\hline $\mathrm{F}_{\mathrm{d}}$ & drag force, $\mathrm{N}$ \\
\hline $\mathrm{J}_{\mathrm{d}}$ & dispersed phase flux, $\mathrm{m} \mathrm{s}^{-1}$ \\
\hline $\mathrm{k}_{\mathrm{wl}}$ & coefficient in Equation (A12) \\
\hline $\mathrm{L}$ & pore spacing (interpore distance), $\mathrm{m}$ \\
\hline $\mathrm{n}_{\mathrm{b}}$ & number of blades \\
\hline $\operatorname{Re}$ & rotational Reynolds number \\
\hline $\mathrm{r}_{1}$ & inner radius of ring membrane, $\mathrm{m}$ \\
\hline $\mathrm{r}_{2}$ & outer radius of ring membrane, $\mathrm{m}$ \\
\hline $\mathrm{r}_{\text {trans }}$ & transitional radius, $\mathrm{m}$ \\
\hline $\mathrm{T}$ & internal diameter of tank, $\mathrm{m}$ \\
\hline$t_{d}$ & drop formation time, $\mathrm{s}$ \\
\hline $\mathrm{r}_{\mathrm{p}}$ & pore radius, $\mathrm{m}$ \\
\hline $\mathrm{V}_{\mathrm{d}}$ & Drop volume, $\mathrm{m}^{3}$ \\
\hline
\end{tabular}


V

$\mathrm{X}$

Greek letters

$\varepsilon$

$\gamma$

$\delta$

$\eta$

$\omega$

$\rho$

$\tau$

$\tau_{\mathrm{av}}$

$\tau_{\max }$ relative velocity between drop and continuous phase, $\mathrm{m} \mathrm{s}^{-1}$ predicted drop diameter, $\mathrm{m}$

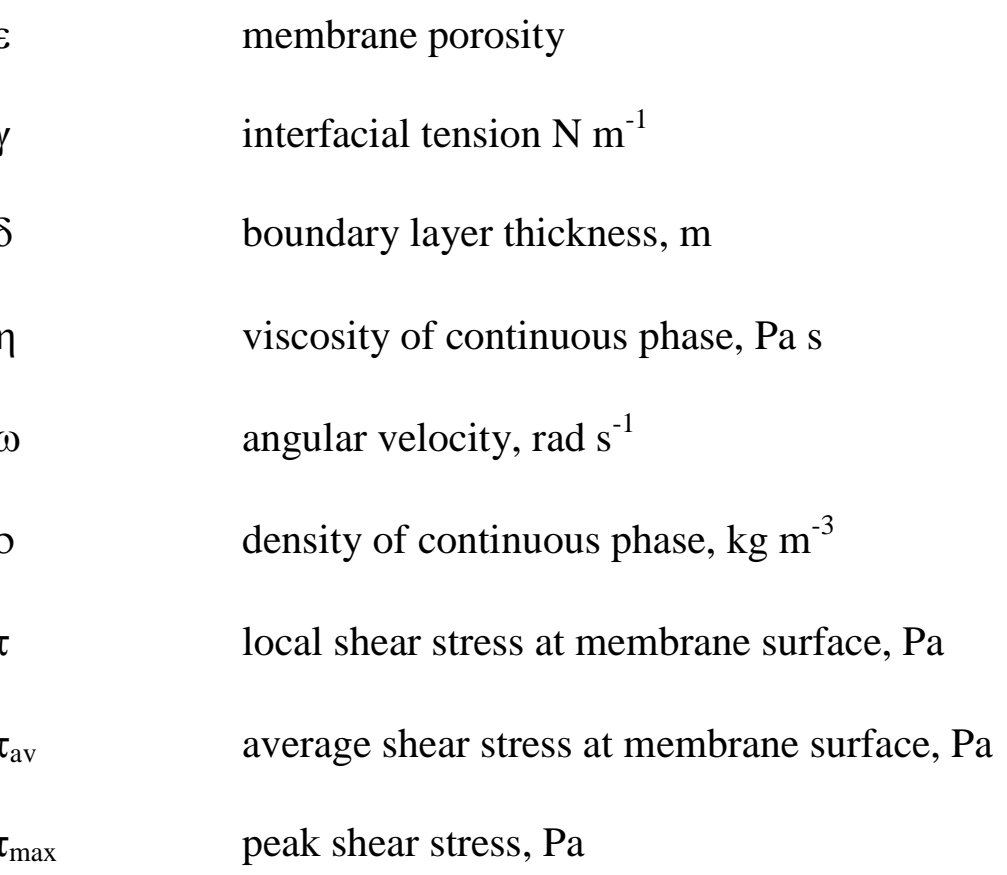

\section{Acknowledgement}

This research was supported by the Ministry for Science and Environmental Protection of the Republic of Serbia (Project No. 142045). The authors whish to thank Gilda Gasparini and Michael T. Stillwell for fruitful discussions and useful advice.

\section{References}

[1] T. Nakashima, M. Shimizu and M. Kukizaki, Particle control of emulsion by membrane emulsification and its applications, Adv. Drug Deliv. Rev., 45 (2000) 47. 
[2] S.M. Joscelyne and G. Trägårdh, Membrane emulsification - a literature review, J. Membr. Sci., 169 (2000) 107.

[3] G.T. Vladisavljević, J. Surh and J.D. McClements, Effect of emulsifier type on droplet disruption in repeated Shirasu Porous Glass membrane homogenization, Langmuir, 22 (2006) 4526.

[4] G.T. Vladisavljević, M. Shimizu and T. Nakashima, Preparation of monodisperse multiple emulsions at high production rates by multi-stage premix membrane emulsification, J. Membr. Sci., 244 (2004) 97.

[5] G.T. Vladisavljević, M. Shimizu and T. Nakashima, Production of multiple emulsions for drug delivery systems by repeated SPG membrane homogenization: Influence of mean pore size, interfacial tension and continuous phase viscosity, J. Membr. Sci., 284 (2006) 373.

[6] J. Hoppe and T. Melin, A new technology for producing mono-disperse macroemulsions, J. Membr. Sci., 303 (2007) 100.

[7] S. van der Graaf, C.G.P.H. Schroën and R.M. Boom, Preparation of double emulsions by membrane emulsification - a review, J. Membr. Sci., 251 (2005) 7.

[8] J. Surh, G.T. Vladisavljević, S. Mun and D.J. McClements, Preparation and characterization of water/oil and water/oil/water emulsions containing biopolymer-gelled water droplets, J. Agric. Food Chem., 55 (2007) 175.

[9] L. Giorno, N. Li and E. Drioli, Use of stable emulsion to improve stability, activity, and enantioselectivity of lipase immobilized in a membrane reactor, Biotechnol. Bioeng., 84 (2003) 677.

[10] G.T. Vladisavljević and R.A. Williams, Recent developments in manufacturing emulsions and particulate products using membranes, Adv. Colloid Interface Sci., 113 (2005) 1. 
[11] M. Kukizaki and M. Goto, Preparation and evaluation of uniformly sized solid lipid microcapsules using membrane emulsification, Colloid. Surf. A, 293 (2007) 87.

[12] G.H Ma, A.Y. Chen, Z.G. Su and S. Omi, Preparation of uniform hollow polystyrene particles with large voids by a glass-membrane emulsification technique and a subsequent suspension polymerization, J. Appl. Polym. Sci., 87 (2003) 244.

[13] T. Fuchigami, M. Toki and K. Nakanishi, Membrane emulsification using sol-gel derived macroporous silica glass, J. Sol-Gel Sci. Technol., 19 (2000) 337.

[14] Q.Z. Zhou, L.Y. Wang, G.H. Ma and Z.G. Su, Preparation of uniform-sized agarose beads by microporous membrane emulsification technique, J. Colloid Interface Sci., 311 (2007) 118.

[15] J.D.H. Kelder, J.J.M. Janssen and R.M. Boom, Membrane emulsification with vibrating membranes: A numerical study, J. Membr. Sci., 304 (2007) 50.

[16] J. Zhu and D. Barrow, Analysis of droplet size during crossflow membrane emulsification using stationary and vibrating micromachined silicon nitride membranes, J. Membr. Sci., 261 (2005) 136.

[17] G.T. Vladisavljević and R.A. Williams, Manufacture of large uniform droplets using rotating membrane emulsification, J. Colloid Interface Sci., 299 (2006) 396.

[18] N. Aryanti, R.A. Williams, R. Hou and G.T. Vladisavljević, Performance of rotating membrane emulsification for o/w production, Desalination, 200 (2006) 572.

[19] V. Schadler and E.J. Windhab, Continuous membrane emulsification by using a membrane system with controlled pore distance, Desalination, 189 (2006) 130.

[20] Y. Hatate, H. Ohta, Y. Uemura, K. Ijichi and H. Yoshizawa, Preparation of monodispersed polymeric microspheres for toner particles by the shirasu porous glass membrane emulsification technique, J. Appl. Polym. Sci., 64 (1997) 1107. 
[21] H. Clare, C.A. Pearson and I.A. Shanks, Method for controlling droplet size of an emulsion when mixing two immiscible fluids, European Patent EP1545754, 2005.

[22] S. Higashi and T. Setoguchi, Hepatic arterial injection chemotherapy for hepatocellular carcinoma with epirubicin aqueous solution as numerous vesicles in iodinated poppy-seed oil microdroplets: clinical application of water-in-oil-in-water emulsion prepared using a membrane emulsification technique, Adv. Drug Del. Rev., 45 (2000) 57.

[23] G.H. Ma, M. Nagai and S. Omi, Preparation of uniform poly(lactide) microspheres by employing the Shirasu Porous Glass (SPG) emulsification technique, Colloid. Surf. A, 153 (1999) 383.

[24] S.R. Kosvintsev, G. Gasparini, R.G. Holdich, I.W. Cumming and M.T. Stillwell, Liquidliquid membrane dispersion in a stirred cell with and without controlled shear, Ind. Eng. Chem. Res., 44 (2005) 9323.

[25] M.T. Stillwell, R.G. Holdich, S.R. Kosvintsev, G. Gasparini and I.W. Cumming, Stirred cell membrane emulsification and factors influencing dispersion drop size and uniformity, Ind. Eng. Chem. Res., 46 (2007), 965.

[26] G. Gasparini, S.R. Kosvintsev, M.T. Stillwell and R.G. Holdich, Preparation and characterization of PLGA particles for subcutaneous controlled drug release by membrane emulsification, Colloid. Surf. B, 61 (2008) 199.

[27] S.R. Kosvintsev, G. Gasparini and R.G. Holdich, Membrane emulsification: droplet size and uniformity in the absence of surface shear, J. Membr. Sci., in press.

[28] I. Kobayashi, M. Nakajima, K. Chun, Y. Kikuchi and H. Fujita, Silicon array of elongated through-holes for monodisperse emulsion droplets, AIChE J., 48 (2002) 1639. 
[29] G.T. Vladisavljević, I. Kobayashi and M. Nakajima, Generation of highly uniform droplets using asymmetric microchannels fabricated on a single crystal silicon plate: effect of emulsifier and oil types, Powder, Technol., in press.

[30] T. Kawakatsu, Y. Kikuchi and M. Nakajima, Regular-sized cell creation in microchannel emulsification by visual microprocessing method, J. Am. Oil Chem. Soc., 74 (1997) 317.

[31] G.T. Vladisavljević, U. Lambrich and M. Nakajima, Production of $\mathrm{O} / \mathrm{W}$ emulsions using SPG membranes, ceramic $\alpha-\mathrm{Al}_{2} \mathrm{O}_{3}$ membranes, microfluidizer and a microchannel plate: a comparative study, Colloid. Surf. A, 232 (2004) 199.

[32] T.A. El-Adawy and K.M. Taha, Characteristics and composition of watermelon, pumpkin, and paprika seed oils and flours, J. Agric. Food Chem., 49 (2001) 1253.

[33] J.H. Xu, G.S. Luo, G.G. Chen and J.D. Wang, Experimental and theoretical approaches on droplet formation from a micrometer screen hole, J. Membr. Sci., 266 (2005) 121.

[34] V. Schröder, O. Behrend and H. Schubert, Effect of dynamic interfacial tension on the emulsification process using microporous, ceramic membranes. J. Colloid Interface Sci., 202 (1998) 334.

[35] M.J. Geerken, R.G.H. Lammertink and M. Wessling, Interfacial aspects of water drop formation at micro-engineered orifices, J. Colloid Interface Sci., 312 (2007) 460.

[36] G.T. Vladisavljević and H. Schubert, Preparation of emulsions with a narrow particle size distribution using microporous $\alpha$-alumina membranes, J. Disper. Sci. Technol., 24 (2003) 811. [37] N.C. Christov, D.N. Ganchev, N.D. Vassileva, N.D. Denkov, K.D. Danov and P.A. Kralchevsky, Capillary mechanisms in membrane emulsification: oil-in-water emulsions stabilized by Tween 20 and milk proteins, J. Colloid Interface Sci., 209 (2002) 83. 
[38] C. Kim and Y.L. Hsieh, Wetting and absorbency of nonionic surfactant solutions on cotton fabrics, Colloid. Surf. A, 187 (2001) 385.

[39] E.V. Batrakova, H.Y. Han, V.Y. Alakhov, D.W. Miller and A.V. Kabanov, Effects of Pluronic block copolymers on drug absorption in caco-2 cell monolayers, Pharm. Res., 15 (1998) 850.

[40] S. van der Graaf, C.G.P.H. Schroën, R.G.M. van der Sman and R.M. Boom, Influence of dynamic interfacial tension on droplet formation during membrane emulsification, J. Colloid Interface Sci., 277 (2004) 456.

[41] S. Nagata, Mixing: Principles and Applications, Kodansha Ltd, Tokyo, Japan, 1975.

[42] L.D. Landau and E.M. Lifshitz, Fluid Mechanics, Pergamon Press, Oxford, U.K., 1959.

[43] H. J. Keh and P.Y. Chen, Slow motion of a droplet between two parallel plane walls, Chem. Eng. Sci., 56 (2001) 6863. 


\section{TABLES}

Table 1. Comparison of different techniques for creation of shear stress at the membrane surface in membrane emulsification

\begin{tabular}{|c|c|c|c|}
\hline & Potential advantages & Potential disadvantages & References \\
\hline Cross flow & $\begin{array}{l}\text { Easy scale-up, constant } \\
\text { shear stress at the } \\
\text { membrane surface, } \\
\text { modules widely available }\end{array}$ & $\begin{array}{l}\text { Droplets can be damaged } \\
\text { during recirculation in } \\
\text { pipes and pumps, long } \\
\text { operation times for } \\
\text { concentrated emulsions }\end{array}$ & {$[1-2]$} \\
\hline $\begin{array}{l}\text { Cross flow }+ \\
\text { membrane } \\
\text { vibration }\end{array}$ & $\begin{array}{l}\text { Additional control over } \\
\text { droplet detachment, } \\
\text { decrease in mean droplet } \\
\text { size as compared with a } \\
\text { simple cross flow }\end{array}$ & $\begin{array}{l}\text { Complicated design, no } \\
\text { evidence that drop size } \\
\text { monodispersity is } \\
\text { improved }\end{array}$ & {$[15-16]$} \\
\hline $\begin{array}{l}\text { Vibration in } \\
\text { continuous phase }\end{array}$ & Simple set-up & $\begin{array}{l}\text { Poor control of shear } \\
\text { stress, suitable only for } \\
\text { small scale applications }\end{array}$ & {$[20-21]$} \\
\hline $\begin{array}{l}\text { Rotating } \\
\text { membrane }\end{array}$ & $\begin{array}{l}\text { Suitable for creation of } \\
\text { fragile particles and } \\
\text { viscous emulsions }\end{array}$ & $\begin{array}{l}\text { Complicated and } \\
\text { expensive design, high } \\
\text { power consumption }\end{array}$ & [17-19] \\
\hline $\begin{array}{l}\text { Stirring, tubular } \\
\text { SPG membrane }\end{array}$ & $\begin{array}{l}\text { Volume of continuous } \\
\text { phase liquid can be as low } \\
\text { as several mililitres }\end{array}$ & $\begin{array}{l}\text { Maximum transmembrane } \\
\text { pressure restricted to } \\
\text { several bars, non-uniform } \\
\text { shear stress at the } \\
\text { membrane surface }\end{array}$ & {$[22-23]$} \\
\hline $\begin{array}{l}\text { Stirring, flat } \\
\text { microengineered } \\
\text { membrane }\end{array}$ & $\begin{array}{l}\text { High injection rates of } \\
\text { dispersed phase through } \\
\text { the membrane }\end{array}$ & $\begin{array}{l}\text { Mean droplet size in } \\
\text { product emulsions above } \\
20 \mu \mathrm{m} \text {, batch operation }\end{array}$ & [24-26] \\
\hline
\end{tabular}


Table 2. The formulation of emulsions in this work

Dispersed phase

Continuous phase

Dispersed phase content

Volume median drop size
Unrefined pumpkin seed oil or refined sunflower oil

2 wt.\% Tween ${ }^{\circledR} 20$ or 1-10 wt.\% Pluronic ${ }^{\circledR}$ F-68 dissolved in Milli-Q water

5-30 vol.\% for pumpkeen seed oil and 5-60 vol.\% for sunflower oil

74-256 and 180-273 $\mu \mathrm{m}$ for the pore size of 19 and $40 \mu \mathrm{m}$, respectively

Table 3. Density and viscosity of surfactant solutions used in this work and equilibrium interfacial tension at oil/aqueous phase interface (solvent: Milli-Q water, temperature: $298 \mathrm{~K}$ )

\begin{tabular}{|c|c|c|c|c|}
\hline Aqueous phase & $\begin{array}{l}\text { Density } \\
\left(\mathrm{kg} \mathrm{m}^{-3}\right)\end{array}$ & $\begin{array}{l}\text { Viscosity } \\
(\mathrm{mPa} s)\end{array}$ & Oil phase & $\begin{array}{c}\text { Interfacial } \\
\text { tension }\left(\mathrm{mN} \mathrm{m}^{-1}\right)\end{array}$ \\
\hline 2 wt. $\%$ Tween 20 & 999.5 & 1.01 & \multirow{7}{*}{$\begin{array}{l}\text { Unrefined } \\
\text { pumpkin } \\
\text { seed oil }\end{array}$} & 1.5 \\
\hline 10 wt.\% Pluronic F68 & 1012 & 4.48 & & 4.5 \\
\hline 6 wt.\% Pluronic F68 & 1006 & 2.61 & & 5.0 \\
\hline 4 wt.\% Pluronic F68 & 1003 & 1.79 & & 5.7 \\
\hline 2 wt.\% Pluronic F68 & 1000 & 1.28 & & 6.0 \\
\hline 1 wt.\% Pluronic F68 & 998.5 & 1.07 & & 6.2 \\
\hline Demineralised water & 997.1 & 0.891 & & 11 \\
\hline 2 wt. $\%$ Tween 20 & & & \multirow{3}{*}{$\begin{array}{l}\text { Refined } \\
\text { sunflower } \\
\text { seed oil }\end{array}$} & 5.0 \\
\hline 2 wt.\% Pluronic F68 & & & & 11.7 \\
\hline Demineralised water & & & & 21.5 \\
\hline
\end{tabular}




\section{FIGURES}

\section{FIGURE CAPTIONS}

Figure 1 Formation of surface shear in membrane emulsification.

Figure 2 Schematic illustration of Dispersion Cell with simple paddle stirrer above a flat-disc membrane $\left(b=12 \mathrm{~mm}, \mathrm{D}=32 \mathrm{~mm}, \mathrm{D}_{\mathrm{m}}=33 \mathrm{~mm}, \mathrm{n}_{\mathrm{b}}=2\right.$, and $\left.\mathrm{T}=40 \mathrm{~mm}\right)$.

Figure 3 (a) Schematic view of the ring membrane (region A indicates pores blocked, region B indicates open pores, and region $\mathrm{C}$ indicates the position where the gasket surrounding the membrane inside the stirred cell sits).

(b) Schematic view of the standard (whole) membrane.

(c) Microscope image of the standard membrane with a pore size of $19 \mu \mathrm{m}$.

(d) Microscope image of the standard membrane with a pore size of $40 \mu \mathrm{m}$.

(e) Schematic view of the pore arrangement, showing a regular hexagonal array of cylindrical pores with a uniform pore spacing of $140 \mu \mathrm{m}$.

Figure 4 Variation of volume median diameter and span of particle size distribution with dispersed phase flux for the whole and ring membrane (dispersed phase: pumpkin seed oil, continuous phase: $2 \%$ Tween 20, rotational speed: 596 rpm, pore size: 19 $\mu \mathrm{m})$.

Figure 5 Variation of average shear stress on the membrane surface with rotational speed for standard and ring membrane (surfactant: $2 \%$ Tween 20).

Figure 6 Distribution of shear stress at the membrane surface for standard (whole) and ring membrane (surfactant: $2 \%$ Tween 20, rotational speed: $596 \mathrm{rpm}$ ).

Figure 7 Variation of volume median diameter and span of a particle size distribution with dispersed phase flux for two different oils (surfactant: $2 \%$ Tween 20, rotational speed $=596 \mathrm{rpm}$, pore size $=19 \mu \mathrm{m}$, dispersed phase content $=5$ vol. $\%$ ). The solid symbols indicate the drop diameters predicted using Model III. This model is based on Equations (A11), (A12), and (A13), given in Appendix.

Figure 8 Variation of volume median diameter and span of a particle size distribution with dispersed phase flux for two different oils (surfactant: $2 \%$ Tween 20, rotational speed $=596 \mathrm{rpm}$, pore size $=19 \mu \mathrm{m}$, dispersed phase content $=5 \mathrm{vol} . \%$ ). The solid symbols indicate the drop diameters predicted using Model III.

Figure 9 Variation of volume median diameter and span of a particle size distribution with final oil concentration for emulsions of pumpkin seed oil and sunflower oil (surfactant: $2 \%$ Tween 20, dispersed phase flux $=318 \mathrm{~L} \mathrm{~m}^{-2} \mathrm{~h}^{-1}$, rotational speed $=596 \mathrm{rpm}$, pore size $=19 \mu \mathrm{m})$. 
Figure 10 Variation of volume median diameter and span of a particle size distribution with dispersed phase flux for two different surfactants (oil phase: pumpkin seed oil, rotational speed $=596 \mathrm{rpm}$, pore size $=19 \mu \mathrm{m}$, dispersed phase content $=5 \mathrm{vol} . \%$ ).

Figure 11 (a) Variation of volume median diameter and span of a particle size distribution with concentration of Pluronic F-68;

Figure 11 (b) particle size distribution at different Pluronic F-68 concentrations.

Conditions: pumpkin seed oil, dispersed phase flux $=318 \mathrm{~L} \mathrm{~m}^{-2} \mathrm{~h}^{-1}$, rotational speed $=$ $596 \mathrm{rpm}$, pore size $=19 \mu \mathrm{m}$, dispersed phase content $=5 \mathrm{vol} . \%$.

Figure 12 Variation of drop size distribution (a) and mean drop size (b) with rotational speed (disperse phase: pumpkin seed oil, continuous phase: $2 \%$ Tween 20, dispersed phase flux $=318 \mathrm{~L} \mathrm{~m}^{-2} \mathrm{~h}^{-1}$, pore size $=19 \mu \mathrm{m}$, dispersed phase content $=5 \mathrm{vol} . \%$ ).

Figure 13 Comparison of experimental drop diameters and predicted values calculated using different models. The values of $\mathrm{d}(\mathrm{v}, 0.5)$ at $0 \mathrm{~L} \mathrm{~m}^{-2} \mathrm{~h}^{-1}$ are obtained by extrapolating experimental $\mathrm{d}(\mathrm{v}, 0.5)$ values to zero flux (dispersed phase: pumpkin seed oil, aqueous phase: $2 \%$ Tween 20, pore size $=19 \mu \mathrm{m}$, dispersed phase content $=5$ vol. $\%$ ). Model I is based on Eq. (A10), in which $\tau=\tau_{\mathrm{av}}$. Model II uses Eq. (A10) in which $\tau=\tau_{\max }$. Model III uses Equations (A11), (A12), and (A13).

Figure 14 Variation of local shear stress on the membrane surface with radial distance from the axis of rotation for $2 \%$ Tween 20, calculated using Equation (A1) or (A2). The vertical short dash-dotted line connects the points at which the surface shear stress is greatest for different rotational speeds.

Figure 15 Variation of transitional radius with rotational speed for different surfactant solutions used in this work, calculated using Equation (A3). 


\section{(a) CROSS FLOW \\ (b) CROSS FLOW + MEMBRANE VIBRATION}

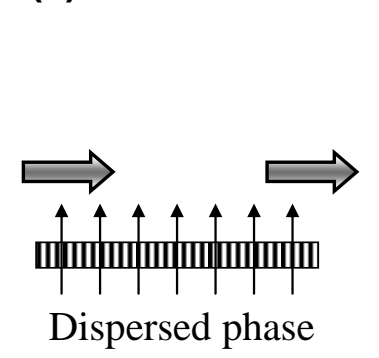

Dispersed phase

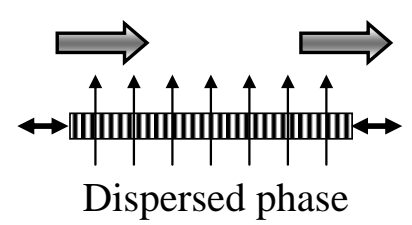

(c) VIBRATION IN CONTINUOUS PHASE

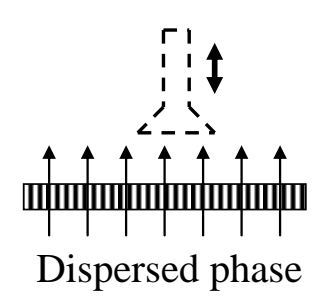

(d) ROTATING MEMBRANE

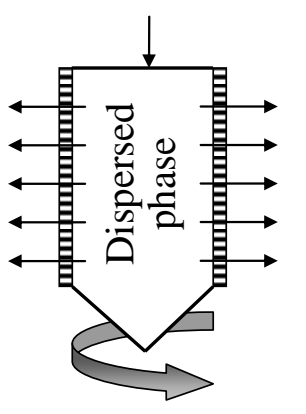

(e) STIRRED CELL, FLAT SHEET MEMBRANE

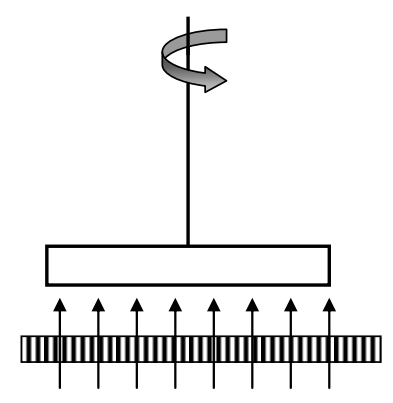

Dispersed phase (f) STIRRED CELL, TUBULAR MEMBRANE

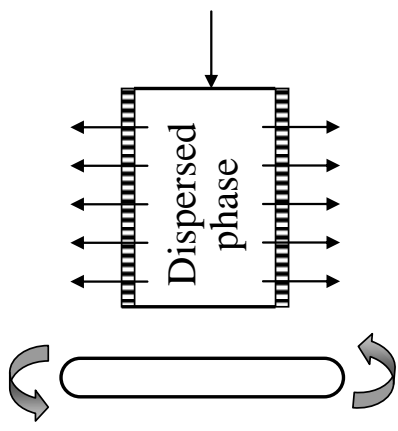

Inside-to-outside

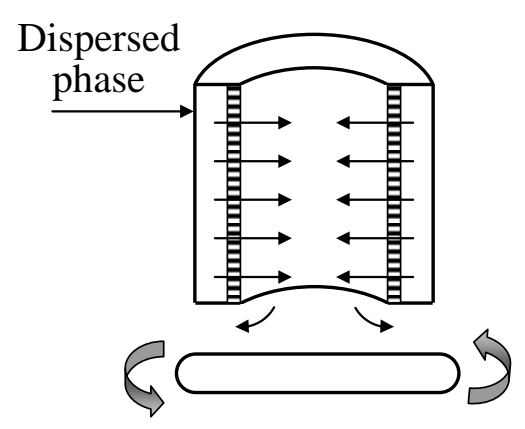

Outside-to-inside

Figure 1 Formation of surface shear in membrane emulsification. 

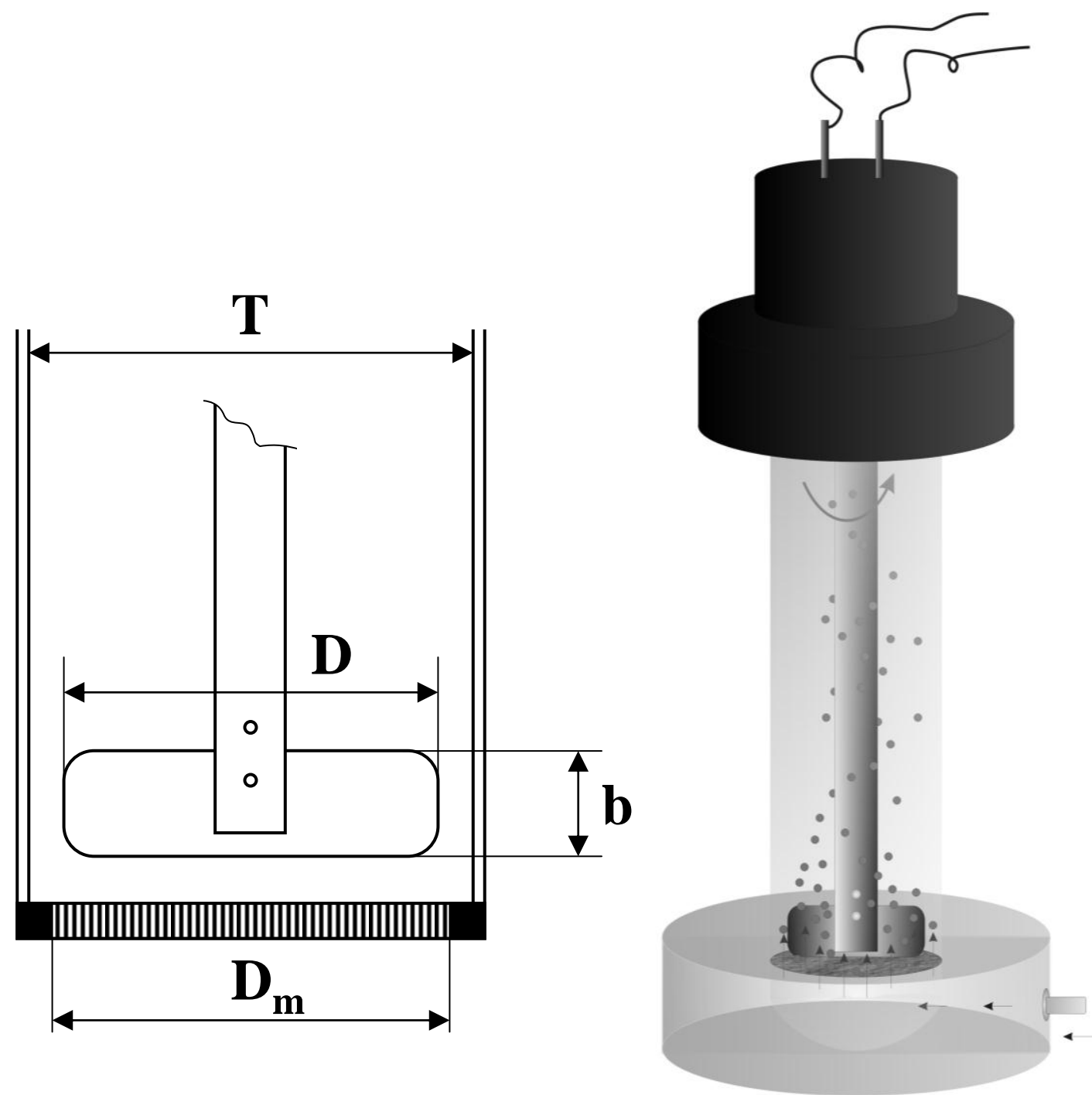

Figure 2 Schematic illustration of Dispersion Cell with simple paddle stirrer above a flat-disc membrane $\left(b=12 \mathrm{~mm}, \mathrm{D}=32 \mathrm{~mm}, \mathrm{D}_{\mathrm{m}}=33 \mathrm{~mm}, \mathrm{n}_{\mathrm{b}}=2\right.$, and $\left.\mathrm{T}=40 \mathrm{~mm}\right)$. 
(a)

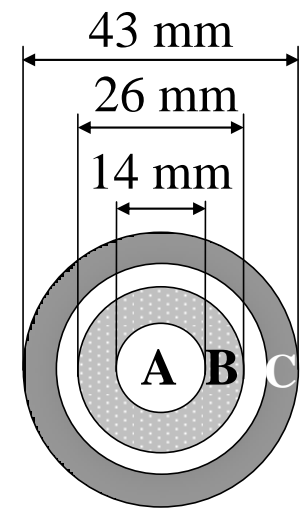

(b)

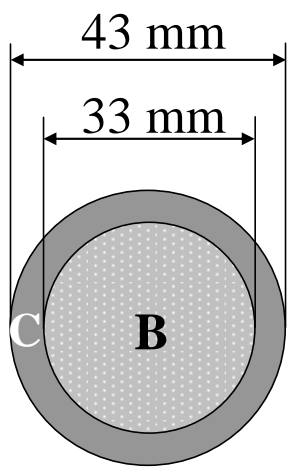

(c)

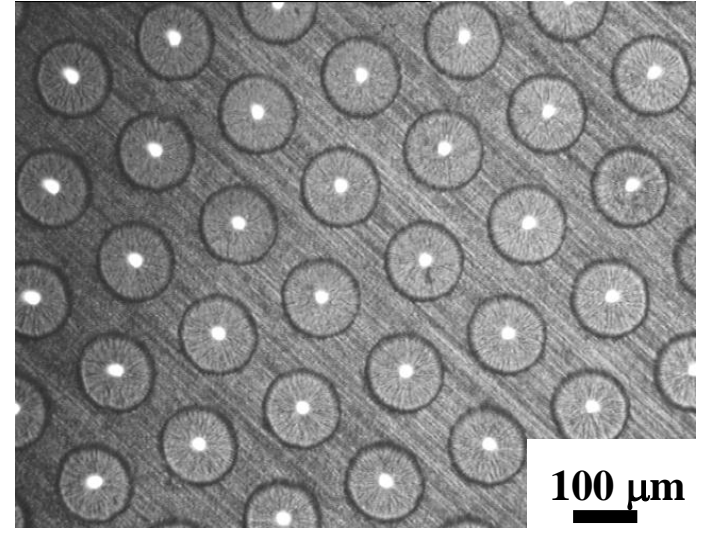

(d)

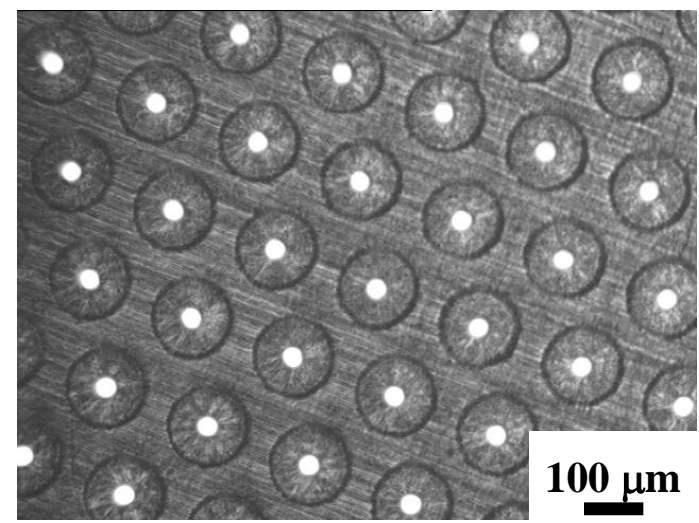

(e)

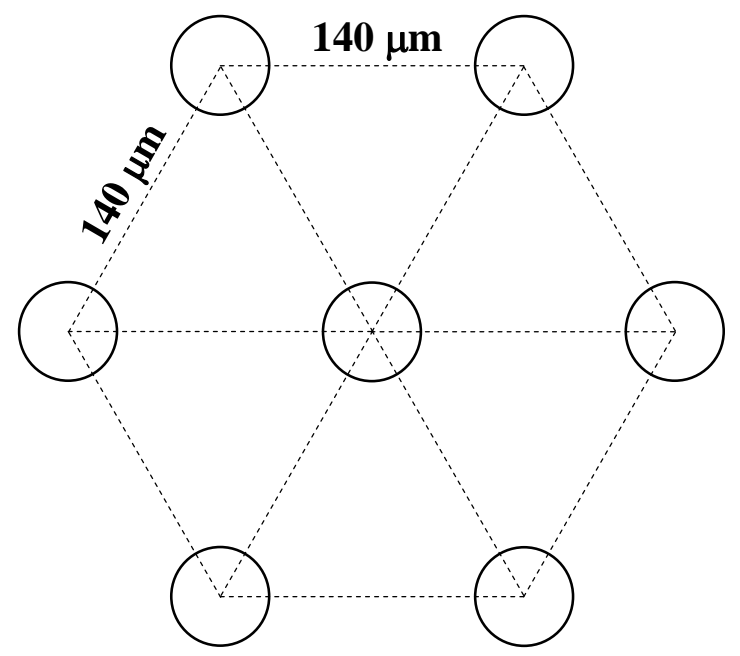

Figure 3 (a) Schematic view of the ring membrane (region A indicates pores blocked, region B indicates open pores, and region $\mathrm{C}$ represents the position where the gasket surrounding the membrane inside the stirred cell sits).

(b) Schematic view of the standard (whole) membrane.

(c) Microscope image of the standard membrane with a pore size of $19 \mu \mathrm{m}$.

(d) Microscope image of the standard membrane with a pore size of $40 \mu \mathrm{m}$.

(e) Schematic view of the pore arrangement, showing a regular hexagonal array of cylindrical pores with a uniform pore spacing of $140 \mu \mathrm{m}$. 

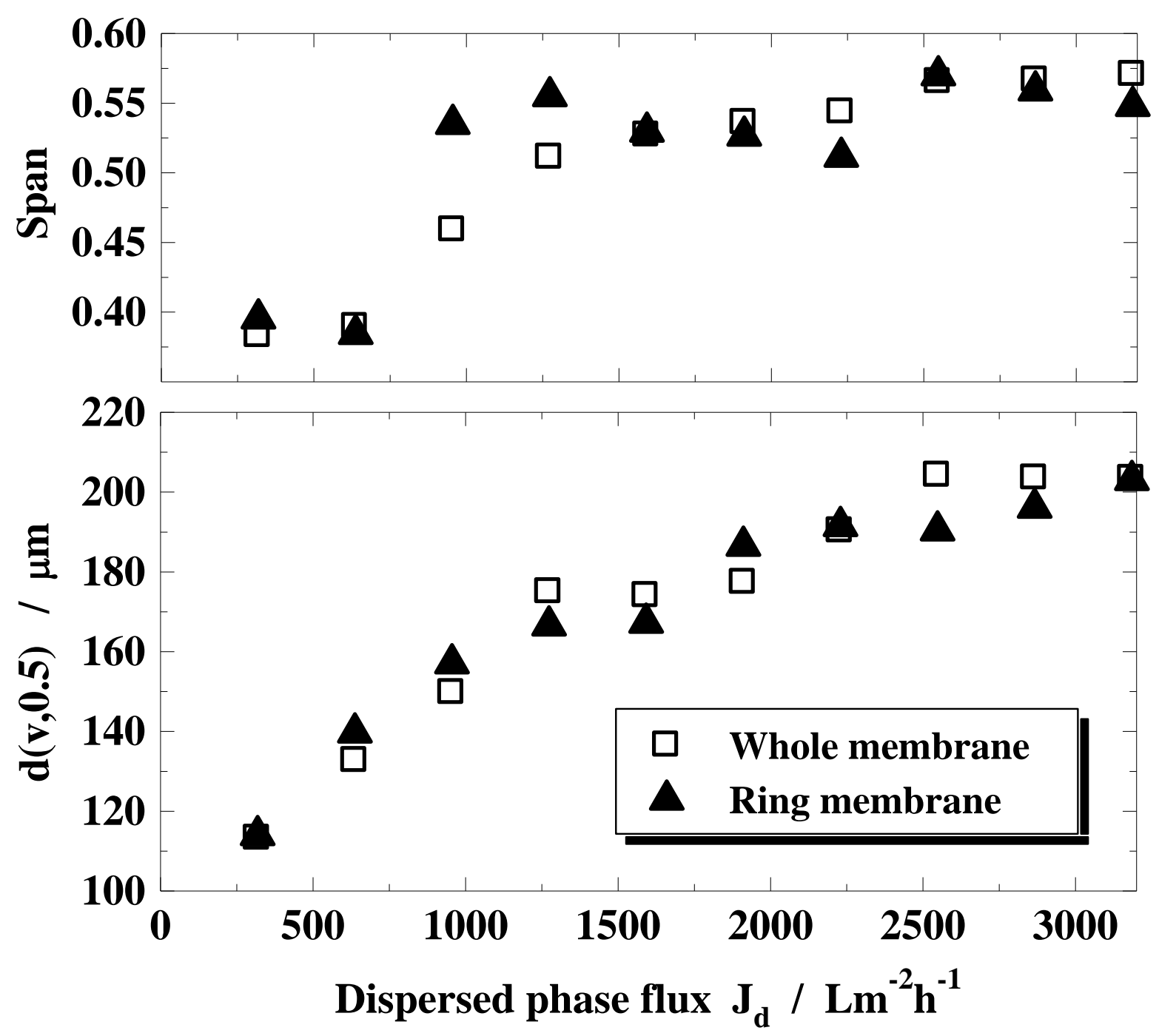

Figure 4 Variation of volume median diameter and span of particle size distribution with dispersed phase flux for the whole and ring membrane (dispersed phase: pumpkin seed oil, continuous phase: $2 \%$ Tween 20, rotational speed: $596 \mathrm{rpm}$, pore size: 19 $\mu \mathrm{m})$. 


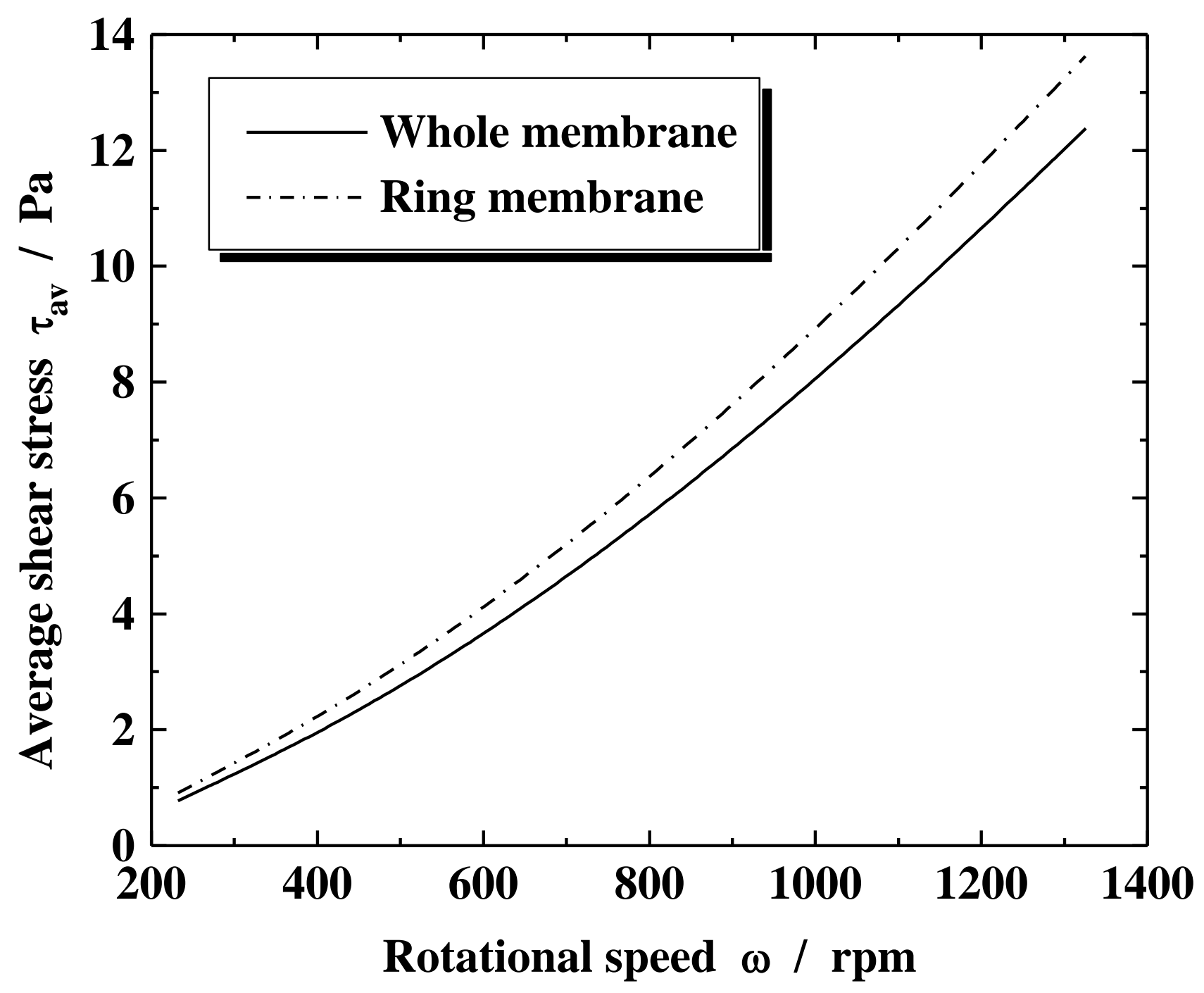

Figure 5 Variation of average shear stress on the membrane surface with rotational speed for standard and ring membrane (surfactant: $2 \%$ Tween 20). 


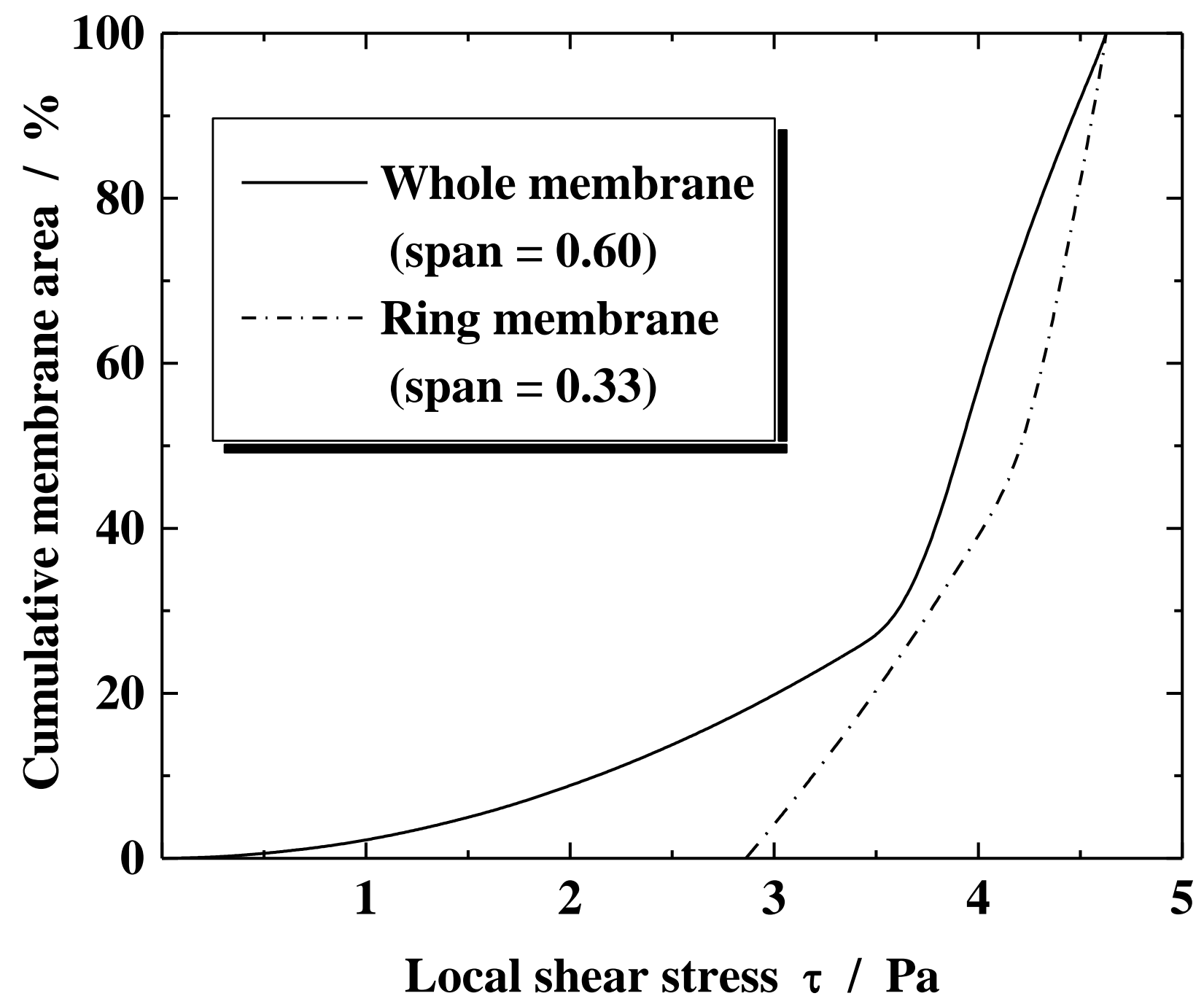

Figure 6 Distribution of shear stress at the membrane surface for standard (whole) and ring membrane (surfactant: $2 \%$ Tween 20, rotational speed: $596 \mathrm{rpm}$ ). 

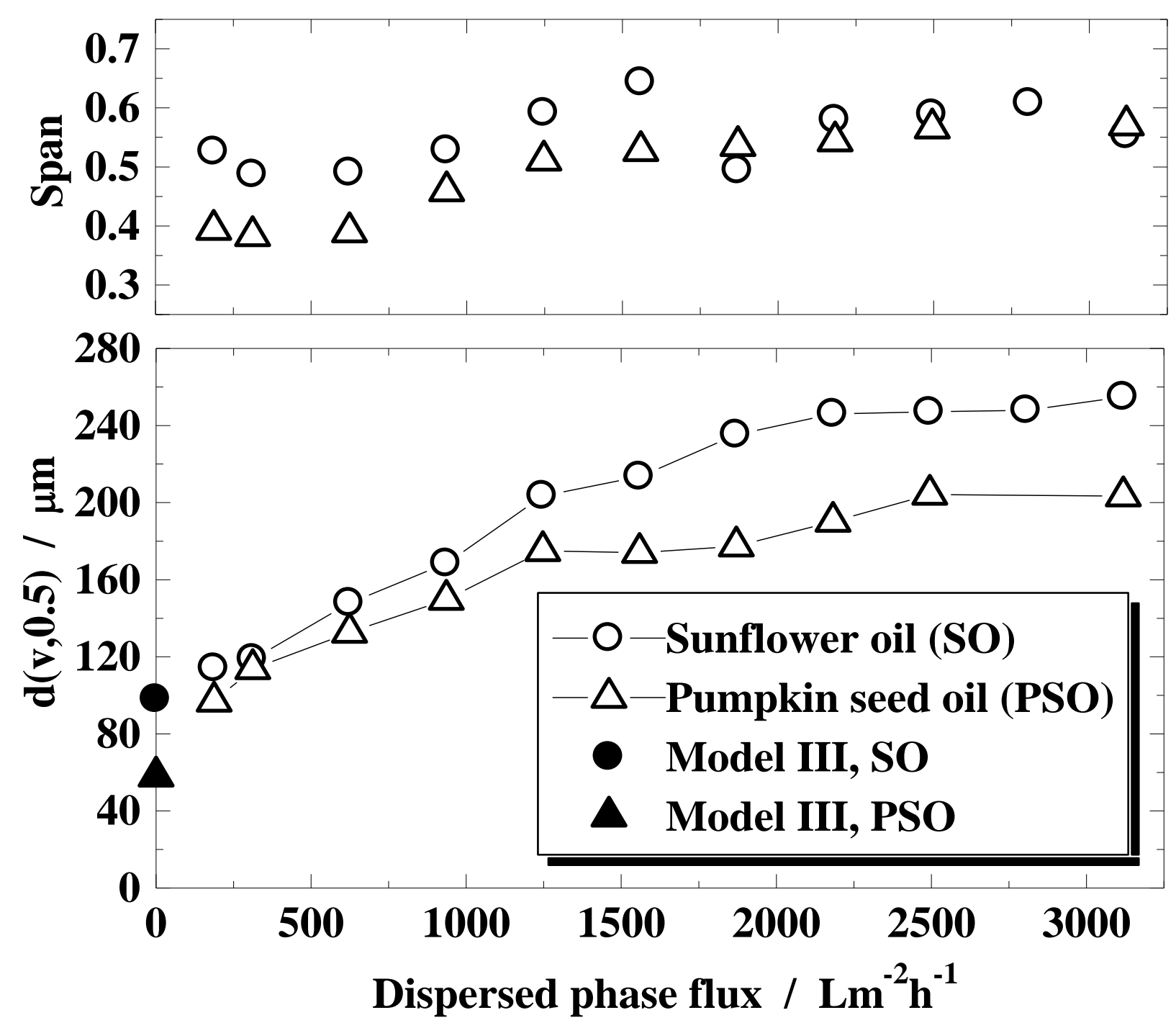

Figure 7 Variation of volume median diameter and span of a particle size distribution with dispersed phase flux for two different oils (surfactant: $2 \%$ Tween 20, rotational speed $=596 \mathrm{rpm}$, pore size $=19 \mu \mathrm{m}$, dispersed phase content $=5 \mathrm{vol} . \%$ ). The solid symbols indicate the drop diameters predicted using Model III. This model is based on Equations (A11), (A12), and (A13), given in Appendix. 


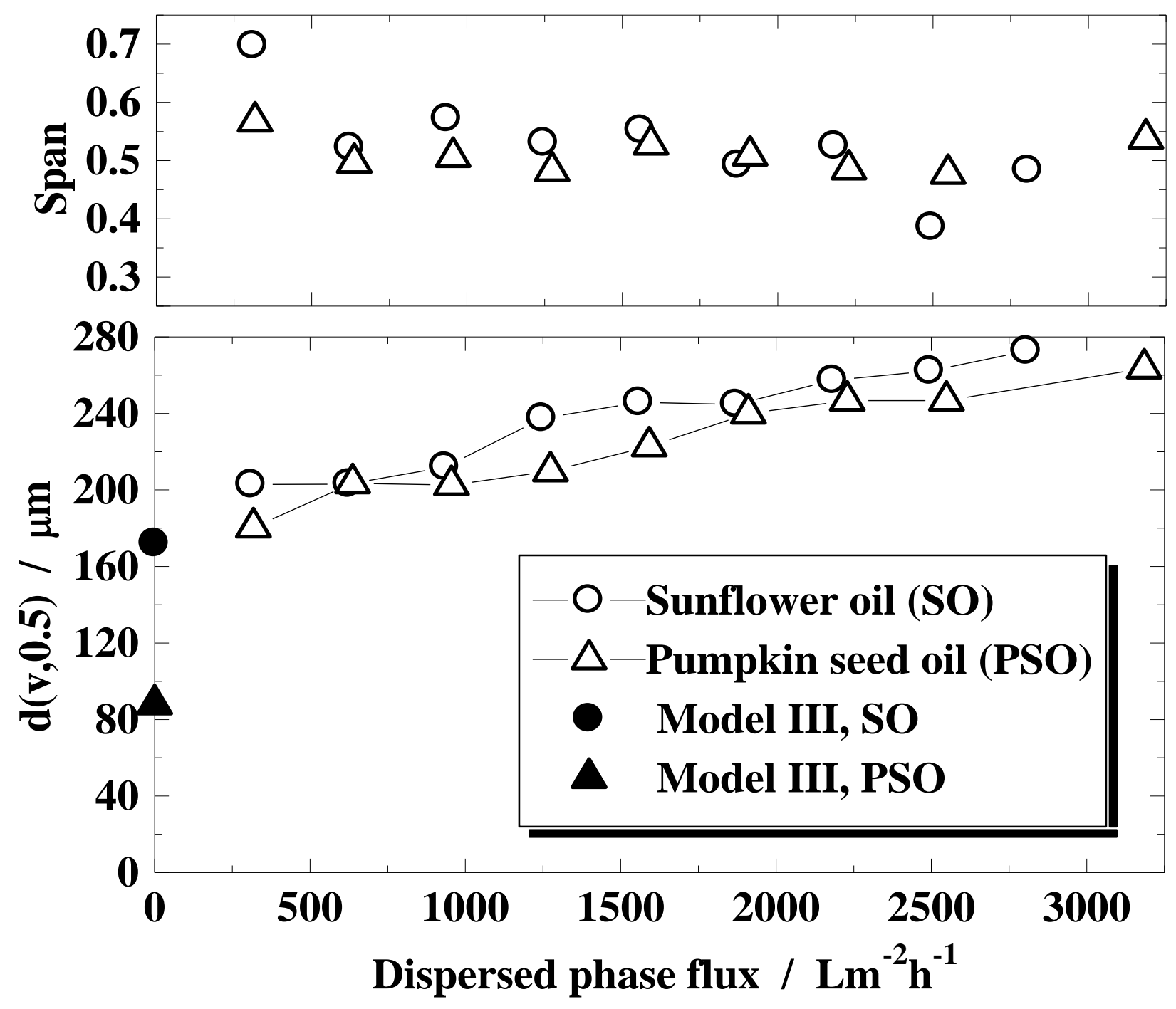

Figure 8 Variation of volume median diameter and span of a particle size distribution with dispersed phase flux for two different oils (pore size $=40 \mu \mathrm{m}$, operating conditions are the same as in Fig. 7). The solid symbols indicate the drop diameters predicted using Model III. 

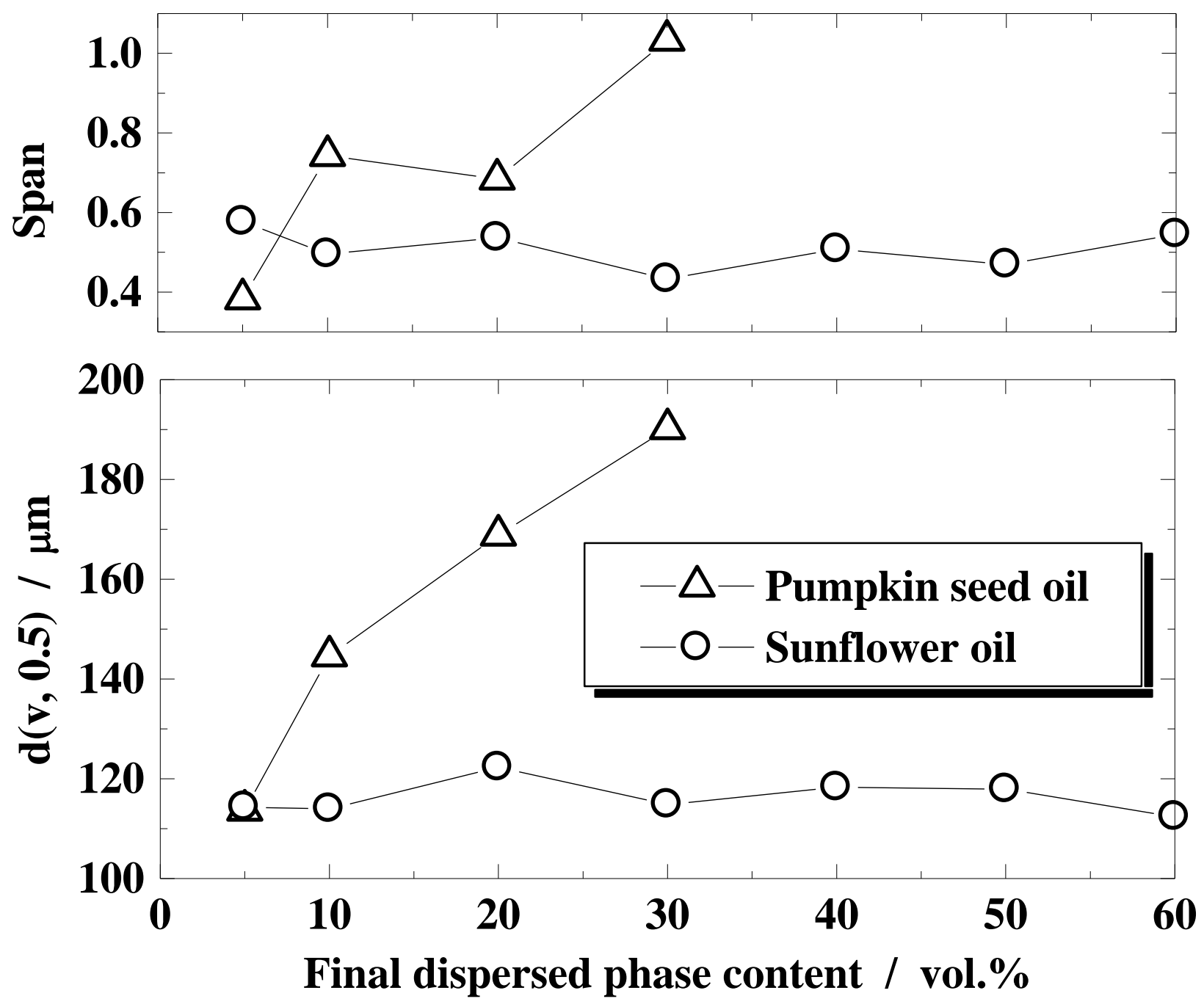

Figure 9 Variation of volume median diameter and span of a particle size distribution with final oil concentration for emulsions of pumpkin seed oil and sunflower oil (surfactant: $2 \%$ Tween 20, dispersed phase flux $=318 \mathrm{~L} \mathrm{~m}^{-2} \mathrm{~h}^{-1}$, rotational speed $=596 \mathrm{rpm}$, pore size $=19 \mu \mathrm{m})$. 

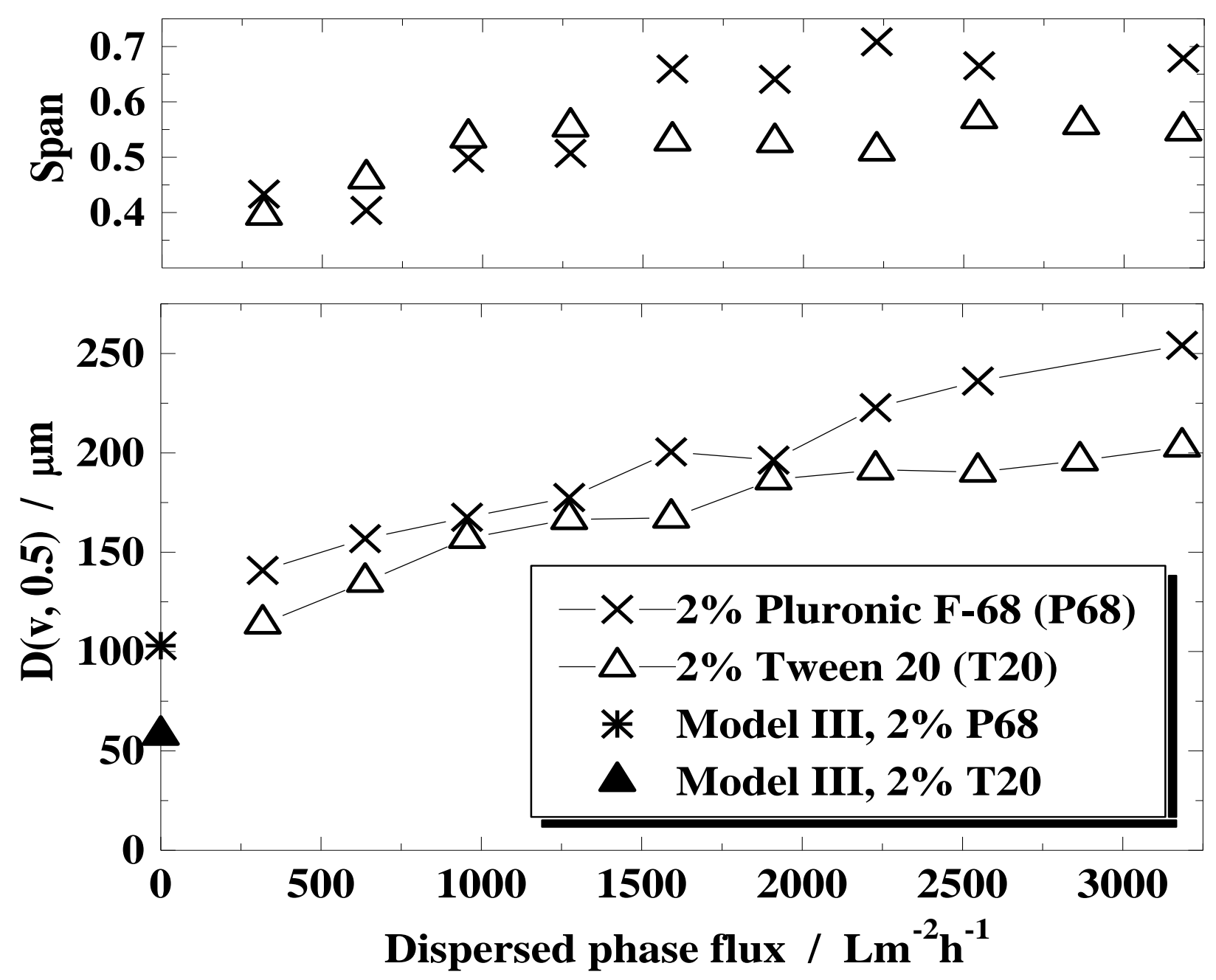

Figure 10 Variation of volume median diameter and span of a particle size distribution with dispersed phase flux for two different surfactants (oil phase: pumpkin seed oil, rotational speed $=596 \mathrm{rpm}$, pore size $=19 \mu \mathrm{m}$, dispersed phase content $=5$ vol. $\%$ ). 
(a)
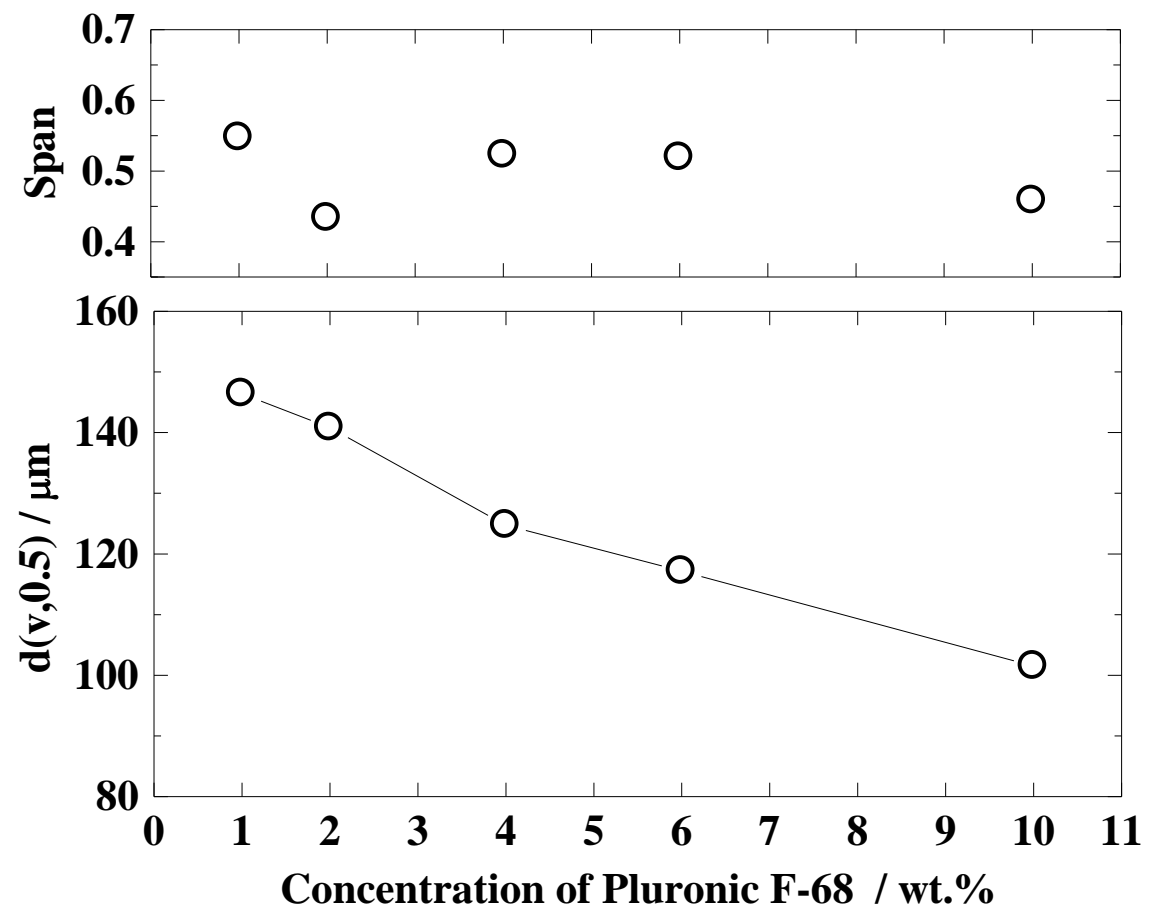

(b)

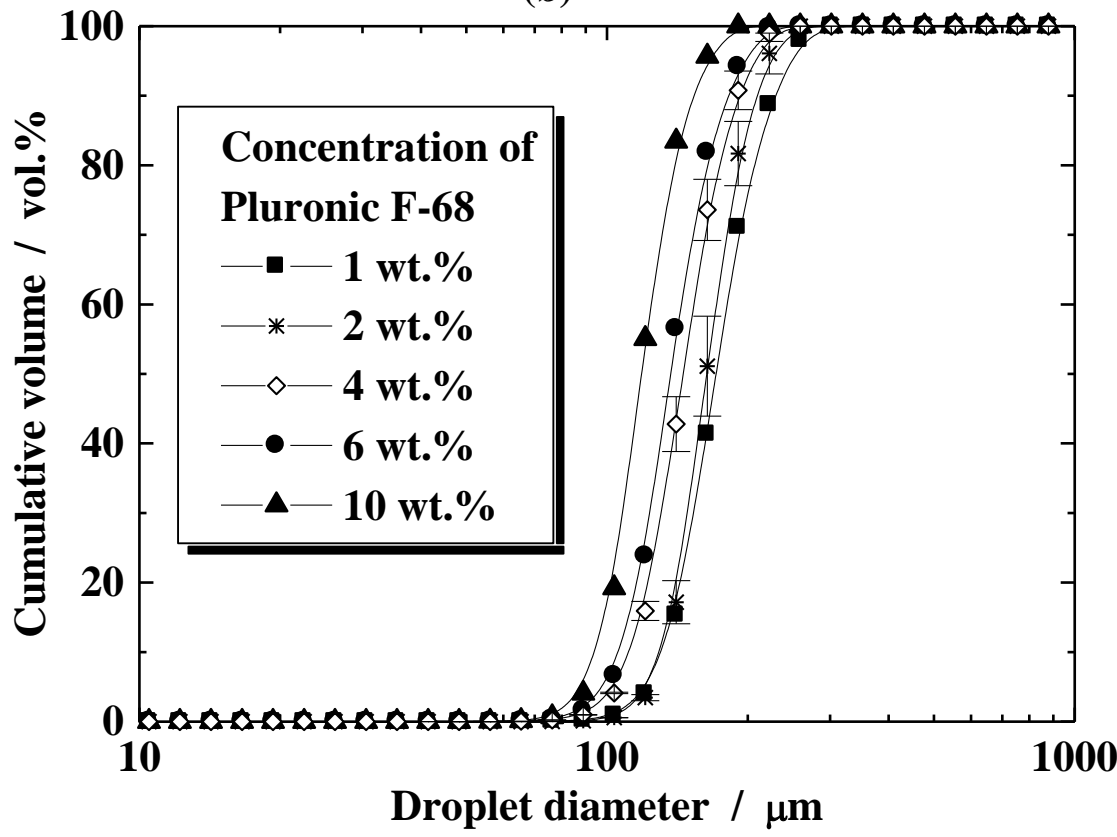

Figure 11 (a) Variation of volume median diameter and span of a particle size distribution with concentration of Pluronic F-68;

Figure 11 (b) particle size distribution at different Pluronic F-68 concentrations.

Conditions: pumpkin seed oil, dispersed phase flux $=318 \mathrm{~L} \mathrm{~m}^{-2} \mathrm{~h}^{-1}$, rotational speed $=$ $596 \mathrm{rpm}$, pore size $=19 \mu \mathrm{m}$, dispersed phase content $=5 \mathrm{vol} . \%$. 
(a)

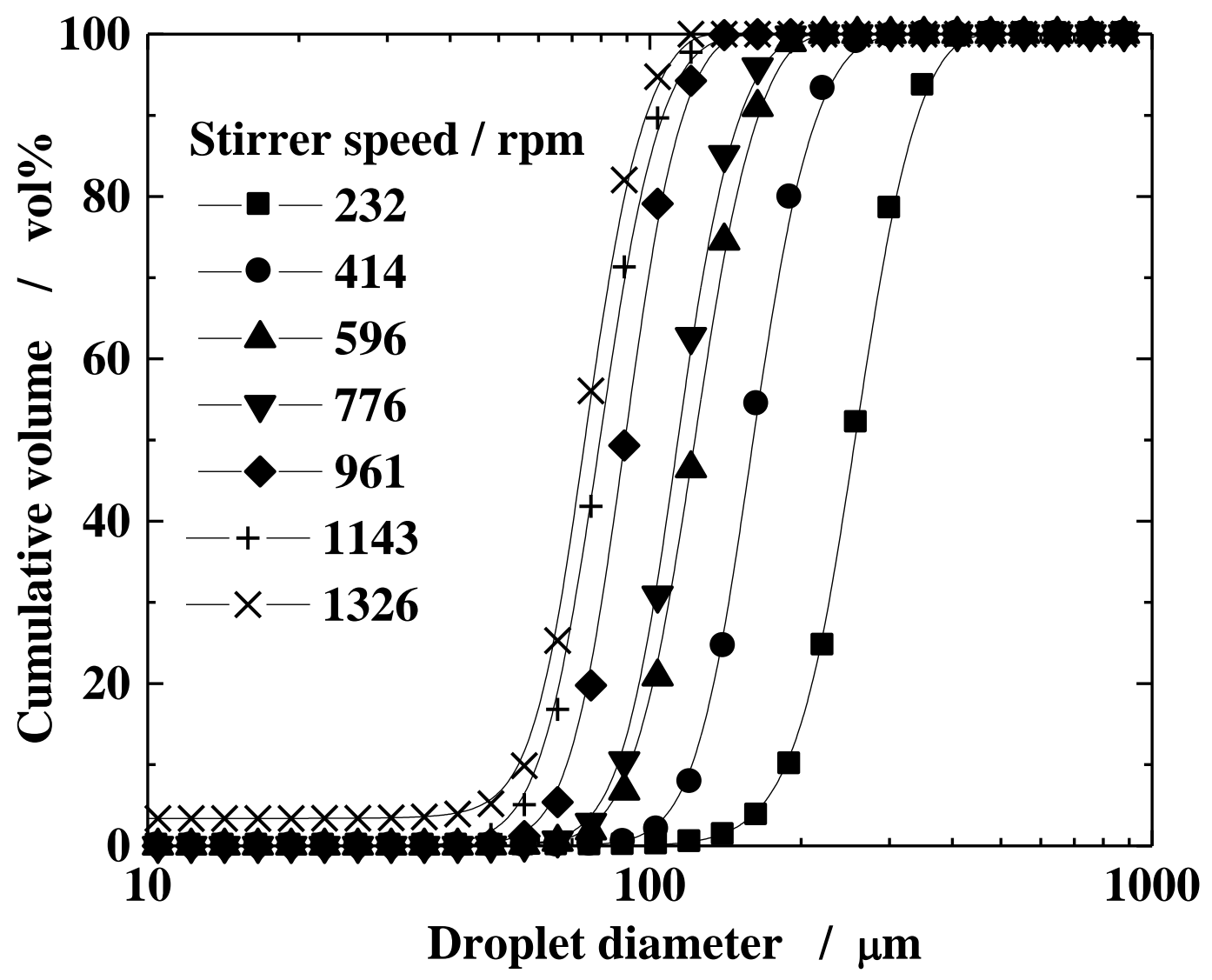

(b)

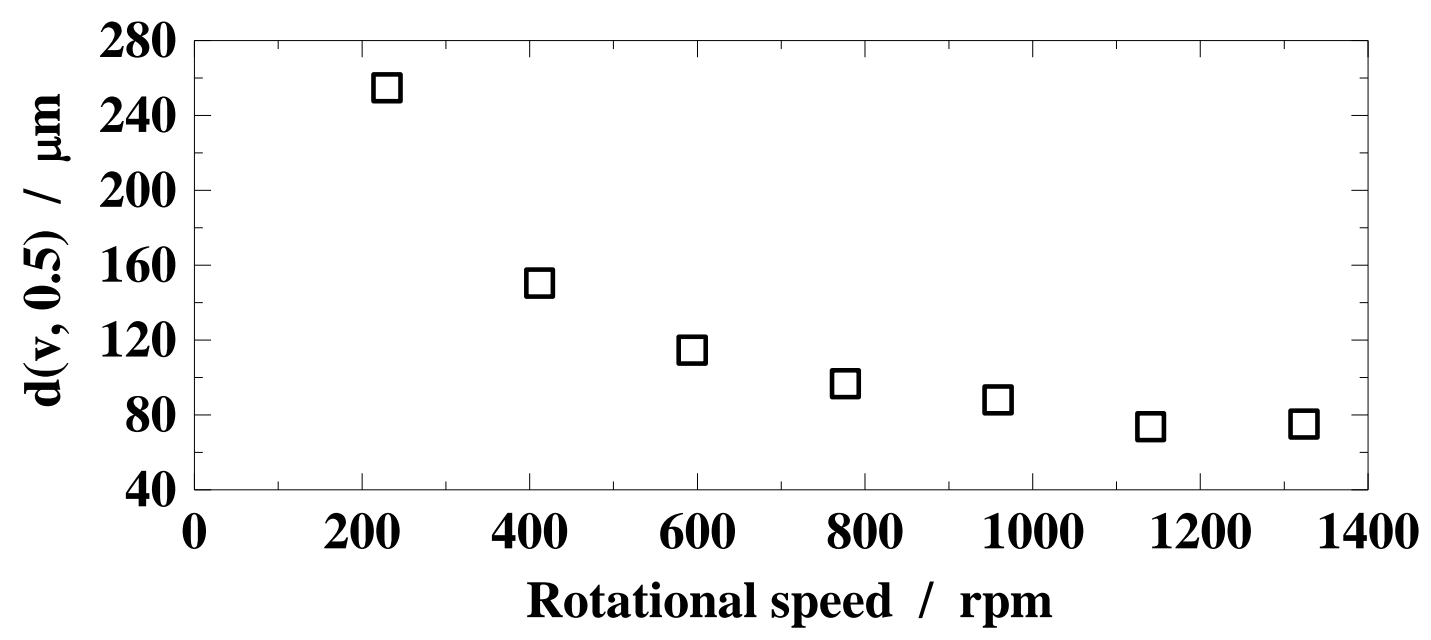

Figure 12 Variation of drop size distribution (a) and mean drop size (b) with rotational speed (disperse phase: pumpkin seed oil, continuous phase: $2 \%$ Tween 20, dispersed phase flux $=318 \mathrm{~L} \mathrm{~m}^{-2} \mathrm{~h}^{-1}$, pore size $=19 \mu \mathrm{m}$, dispersed phase content $=5$ vol. $\%$ ). 


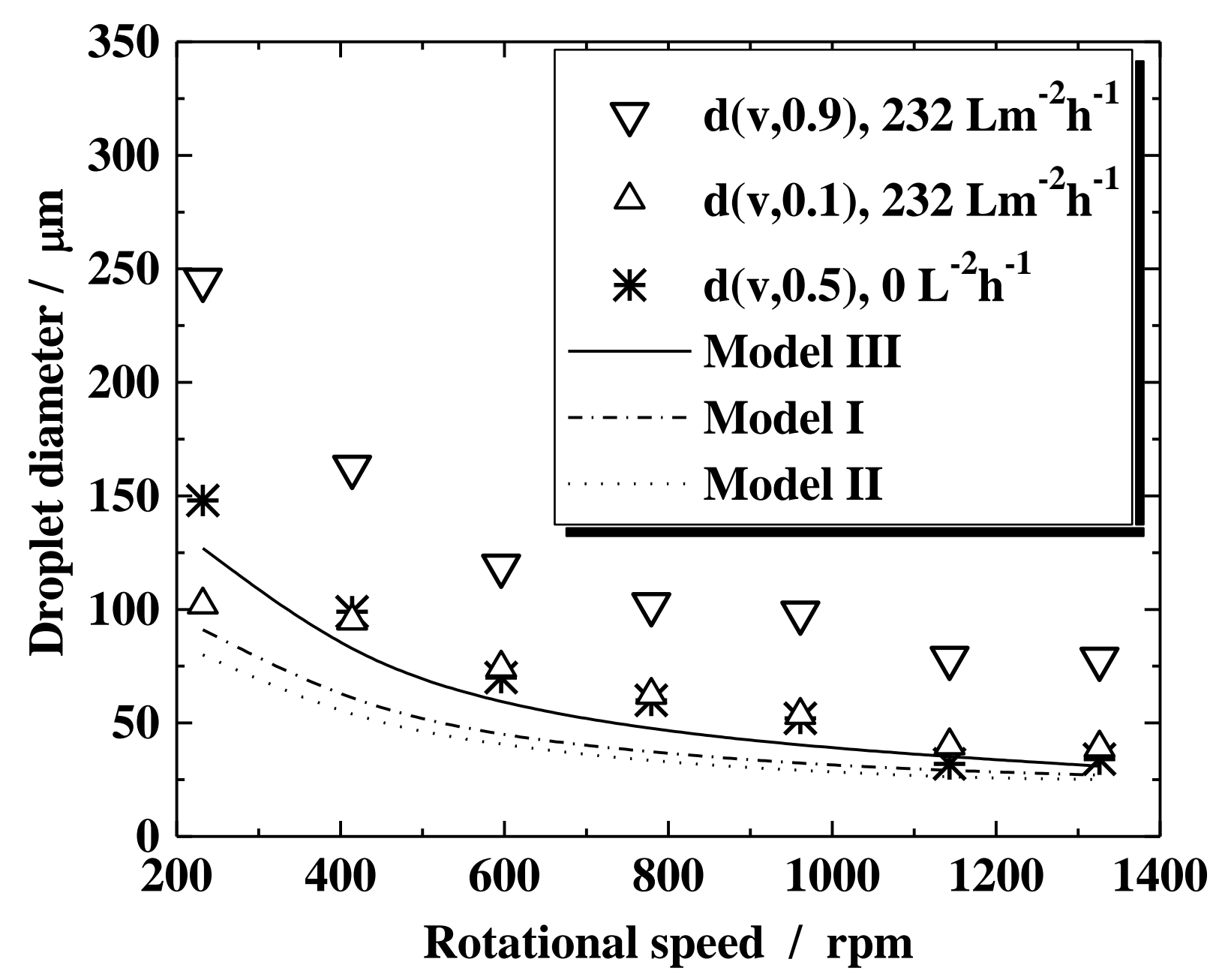

Figure 13 Comparison of experimental drop diameters and predicted values calculated using different models. The values of $\mathrm{d}(\mathrm{v}, 0.5)$ at $0 \mathrm{~L} \mathrm{~m}^{-2} \mathrm{~h}^{-1}$ are obtained by extrapolating experimental $\mathrm{d}(\mathrm{v}, 0.5)$ values to zero flux (dispersed phase: pumpkin seed oil, aqueous phase: $2 \%$ Tween 20, pore size $=19 \mu \mathrm{m}$, dispersed phase content $=5$ vol. $\%$ ). Model I is based on Eq. (A10), in which $\tau=\tau_{\text {av }}$. Model II uses Eq. (A10) in which $\tau=\tau_{\max }$. Model III uses Equations (A11), (A12), and (A13). 


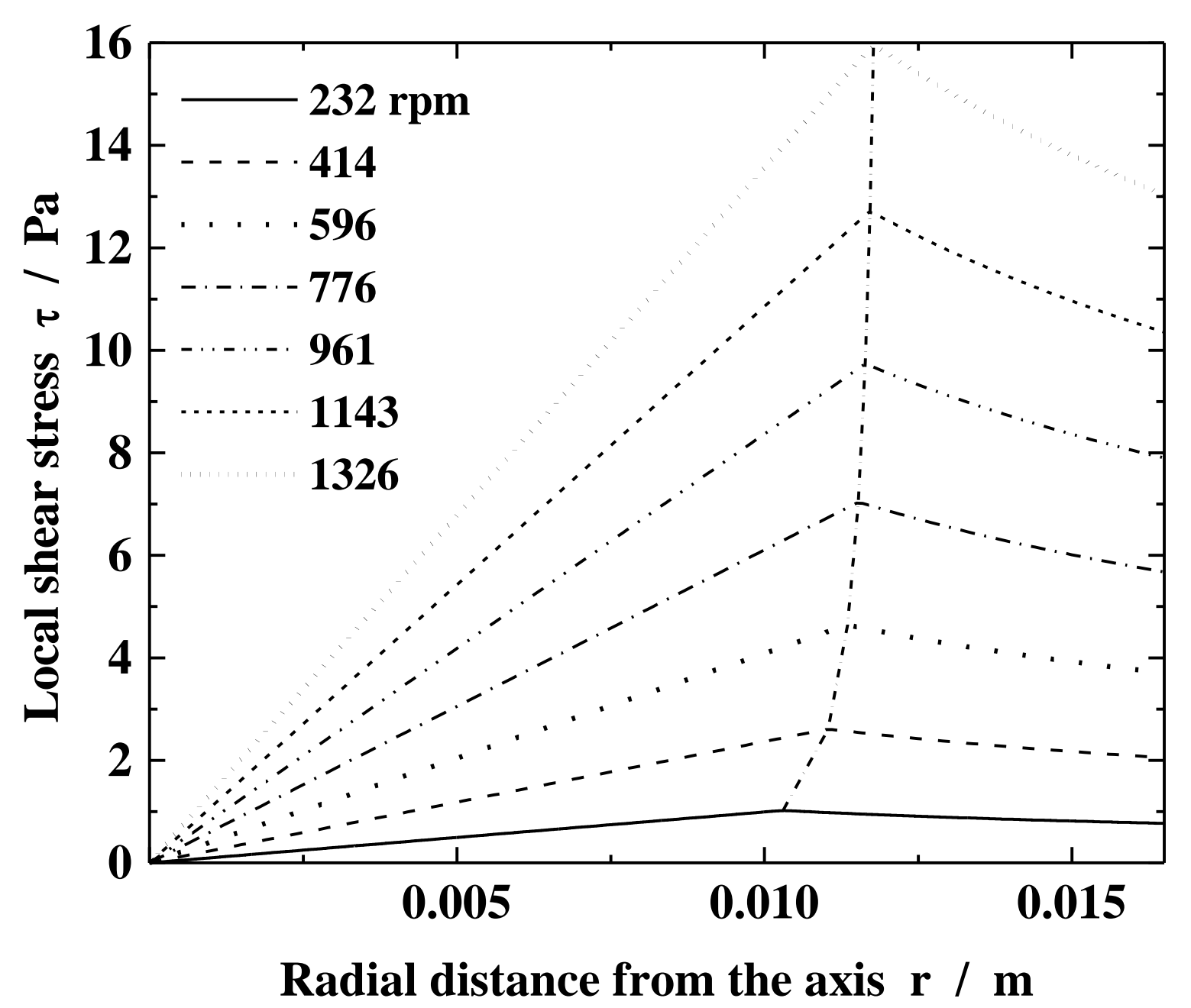

Figure 14 Variation of local shear stress on the membrane surface with radial distance from the axis of rotation for $2 \%$ Tween 20, calculated using Equation (A1) or (A2). The vertical short dash-dotted line connects the points at which the surface shear stress is greatest for different rotational speeds. 


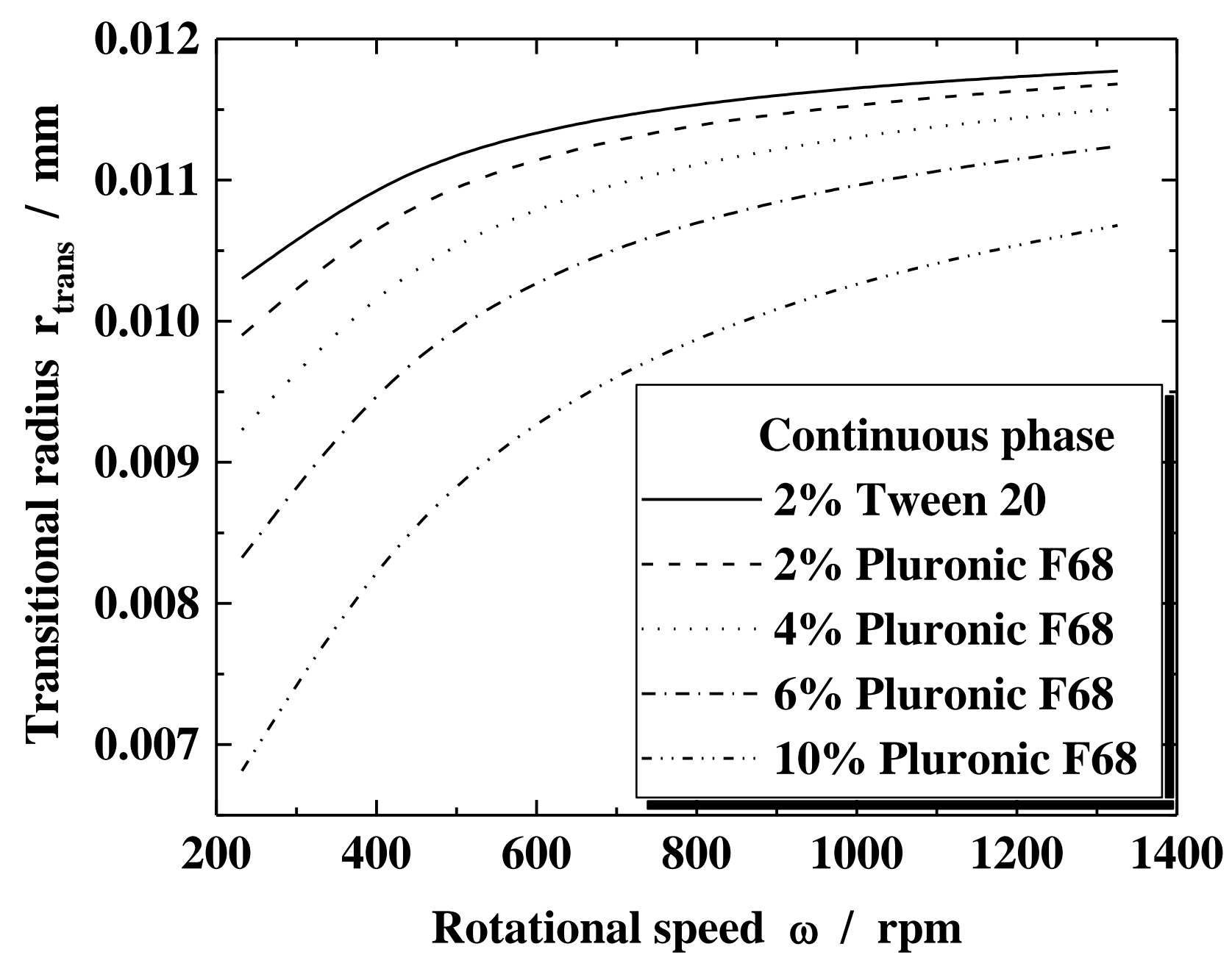

Figure 15 Variation of transitional radius with rotational speed for different surfactant solutions used in this work, calculated using Equation (A3). 